\title{
Culturally significant fisheries: keystones for management of freshwater social-ecological systems
}

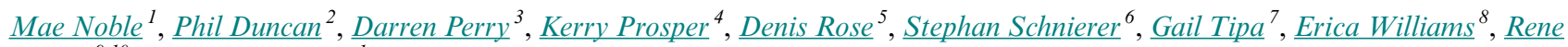

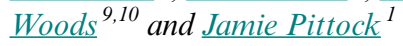

\begin{abstract}
Indigenous peoples of North America, Australia, and New Zealand have a long tradition of harvesting freshwater animals. Over generations of reliance and subsistence harvesting, Indigenous peoples have acquired a profound understanding of these freshwater animals and ecosystems that have become embedded within their cultural identity. We have identified trans-Pacific parallels in the cultural significance of several freshwater animal groups, such as eels, other finfish, bivalves, and crayfish, to Indigenous peoples and their understanding and respect for the freshwater ecosystems on which their community survival depends. In recognizing such cultural connections, we found that non-Indigenous peoples can appreciate the deep significance of freshwater animals to Indigenous peoples and integrate Indigenous stewardship and Indigenous ecological knowledge into effective comanagement strategies for sustainable freshwater fisheries, such as Indigenous rangers, research partnerships, and Indigenous Protected Areas. Given that many of these culturally significant freshwater species also play key ecological roles in freshwater ecosystems, their recognition and prioritization in management and monitoring approaches should help sustain the health and well-being of both the social and ecological components of freshwater ecosystems.
\end{abstract}

Key Words: adaptive freshwater management; aquatic resources; bivalve; comanagement; crayfish; cultural keystone species; eel; Indigenous ecological knowledge; Indigenous water rights; lamprey; salmon; social-ecological resilience

\section{INTRODUCTION}

Freshwaters are often an intrinsic part of place and central to linking human values and relationships with areas of cultural significance (Langton 2002, 2006, Harmsworth et al. 2011). Accordingly, many Indigenous peoples have value systems and concepts that recognize interconnections between people and freshwaters (Table 1), which typically seek to balance the human use of freshwaters by respecting them as a gift (e.g., Blackstock 2001, Tipa 2013) and harvesting in a manner that does not compromise ecosystem integrity (Kahui and Richards 2014). Indigenous people have managed their freshwater environments accordingly for thousands of years (Haggen et al. 2006, Gunditjmara people 2010, Aboriginal Water Initiative 2012), often with a keen awareness of seasonal cycles of hydrological change (Blackstock 2001). Through thousands of years of stewardship, Indigenous peoples have developed deep cultural connections to freshwaters and the freshwater animals that help maintain their cultural, social, and economic health and wellbeing.

Aquatic animals are often central to human connections to freshwaters by providing an important food source and/or a focal point for culturally significant events, ceremonies, and intergenerational teachings about the natural world (Cristancho and Vining 2004, Garibaldi and Turner 2004, Schnierer 2011, Alfred 2014). As such, these cultural keystone species (CKS) influence the cultural identity of a group of people via the species role in subsistence, spirituality, and/or Indigenous economies (Garibaldi and Turner 2004, Butler et al. 2012, McCarthy et al. 2014). Maintaining connections to these species through traditional practices is crucial for the social-ecological resilience of Indigenous cultures. Despite this importance, freshwater CKS are often not formally recognized in modern management and monitoring approaches, which have traditionally focused on threatened species and, more recently, ecological keystone species that perform key roles in maintaining biodiversity, ecosystem health, and bolstering resilience to disturbance (Bond 1994, Gunderson 2000, Caro 2010). Equitable integration of Indigenous ecological knowledge (IEK) into modern fisheries management can empower Indigenous people via recognition of their sovereignty (Bohnesky and Maru 2011, Alfred 2014) and support of customary harvest values and practices (Schnierer 2011, Butler et al. 2012). If we are to bolster social-ecological resilience in freshwaters, we must recognize culturally significant species, engage a range of people in building cross-cultural capacity and understanding of freshwaters, and include IEK in adaptive management plans (Berkes et al. 2000, Moller et al. 2004, Stephenson and Moller 2009, Ruiz-Mallén and Corbera 2013).

In this review, we explore the cultural significance of some key freshwater animals that underpin Indigenous fisheries and communities around the world and how their recognition as CKS can enhance management approaches to sustain Indigenous and non-Indigenous people, as well as the freshwater ecosystem goods and services on which we all depend. We focus on freshwater animal groups with cross-continental importance to draw on multicultural examples of Indigenous freshwater fisheries management in North America, including the United States and Canada; Australia; and New Zealand. Our specific aims were to (1) identify species that facilitate cultural connections to freshwaters and have cross-cultural, ecological, and economic importance; (2) explore cross-cultural approaches to fisheries

\footnotetext{
${ }^{1}$ Fenner School of Environment and Society, The Australian National University, ${ }^{2}$ Gamilaroi Traditional Owner, NSW Aboriginal Land Council, ${ }^{3}$ Murray Lower Darling Rivers Indigenous Nations, ${ }^{4}$ Paq'tnekek Mi'kmaq First Nations, ${ }^{5}$ Gunditj Mirring Traditional Owners Aboriginal Corporation, ${ }^{6}$ School of Environment, Science and Engineering, Southern Cross University, ${ }^{7}$ Tipa and Associates Ltd., ${ }^{8}$ National Institute of Water and Atmospheric Research, ${ }^{9}$ National Cultural Flows Program, ${ }^{10}$ Murray Lower Darling River Indigenous Nations
} 
Table 1. Examples of the terms used to embody Indigenous approaches to stewardship of fisheries and/or freshwaters in North America, Australia, and New Zealand.

\begin{tabular}{|c|c|c|c|}
\hline Indigenous Group & Location & Term & Description \\
\hline First Nations & $\begin{array}{l}\text { North } \\
\text { America }\end{array}$ & $\begin{array}{l}\text { Fons et origio (Blackstock } \\
\text { 2001) }\end{array}$ & Describes source of all possible existence and symbolizes potentiality of nature. \\
\hline Mi’kmaq & $\begin{array}{l}\text { North } \\
\text { America }\end{array}$ & $\begin{array}{l}\text { Netukulimk (Prosper et } \\
\text { al. 2011) }\end{array}$ & $\begin{array}{l}\text { Holistic natural resource management concept that ensures sustainability and } \\
\text { prosperity of a resource for the present and future generations. }\end{array}$ \\
\hline \multirow{3}{*}{$\begin{array}{l}\text { Mid-Columbia } \\
\text { Plateau Tribes } \\
\text { (Sahaptin native } \\
\text { language) }\end{array}$} & North & Shukwat (Close et al. & All life believed to have a spirit and a conscience. Promotes respect for all things in \\
\hline & America & 2002) & nature and is interwoven with Sahaptin culture via myths and legends. \\
\hline & & $\begin{array}{l}\text { Tamanwit (Close et al. } \\
\text { 2002) }\end{array}$ & $\begin{array}{l}\text { Sacred law of how humans should live with the brothers and sisters of the natural } \\
\text { world. If someone abuses Tamanwit, the Shukwat will make life difficult for that } \\
\text { person. }\end{array}$ \\
\hline \multirow[t]{3}{*}{ Māori } & New Zealand & $\begin{array}{l}\text { Mauri (Marsden and } \\
\text { Henare 1992) }\end{array}$ & $\begin{array}{l}\text { The binding force between the physical and the spiritual that interpenetrates all } \\
\text { things to bind and knit them together. The capacity for air, water, or soil to support } \\
\text { life. Mauri is found in water, land, and forests, as well as mist, wind, soil, and rocks. }\end{array}$ \\
\hline & & $\begin{array}{l}\text { Mātauranga Māori } \\
\text { (Waitangi Tribunal 2011) }\end{array}$ & $\begin{array}{l}\text { The unique Māori way of viewing the world, a dynamic and evolving knowledge } \\
\text { system encompassing traditional knowledge, language, and culture. }\end{array}$ \\
\hline & & $\begin{array}{l}\text { Kaitiakitanga (Roberts et } \\
\text { al. 1995) }\end{array}$ & $\begin{array}{l}\text { The inherited nurtured responsibility of Māori to look after the resources within their } \\
\text { tribal area. Derived from the verb tiaki, which means to guard, to protect, to keep, to } \\
\text { watch for, to wait for. }\end{array}$ \\
\hline Aboriginal & Australia & $\begin{array}{l}\text { Various (Langton 2002, } \\
\text { 2006) }\end{array}$ & $\begin{array}{l}\text { Multiple regional terms used across Australia to represent each tribes' strong } \\
\text { connections to freshwaters as part of their spiritual and cultural identity. A common } \\
\text { belief is the following: "If the water is healthy, Country is healthy. If Country is } \\
\text { healthy then the People and Culture will be healthy" (Moggridge and Mihinui } \\
\text { 2010:1). }\end{array}$ \\
\hline
\end{tabular}

management, using the case study of freshwater eels to illustrate the diversity of approaches and benefits of recognizing culturally significant freshwater animals; (3) examine barriers and issues with Indigenous access to culturally significant fisheries; and (4) suggest future approaches to improve freshwater management via recognition of CKS and adoption of IEK in comanagement, research partnerships, and Indigenous custodianship.

\section{CULTURALLY SIGNIFICANT FRESHWATER FISHERIES}

Our exploration of Indigenous freshwater fisheries in North America, Australia, and New Zealand identified four common animal groups playing particularly important cultural roles within the Indigenous communities of these nations: eels/ lampreys, other finfish, freshwater bivalves, and crayfish. Through their role in traditional subsistence foods, ceremonies, celebrations, and/or other spiritual practices, these freshwater animals reveal some trans-Pacific similarities in Indigenous recognition and values, as well as some notable differences (Tables 2-5). Ecological research to date also suggests that many of these freshwater animals are vital for maintaining good water quality, nutrient cycling, trophic webs, habitat engineering, and/or other key components of freshwater ecosystem integrity and function. We explore both the cross-cultural and ecological importance of these freshwater animals, as well as the extent to which these species fit the characteristics described by Garibaldi and Turner (2004) to be recognized as CKS.

\section{Eels and lampreys}

Eels (Anguilliformes) and lampreys (Petromyzontiformes) are eel-shaped fishes that are thought to be CKS because of their central role in trans-Pacific Indigenous cultures as food, medicines, and raw materials in ceremonies and celebrations (Table 2). Eels and lampreys undergo large migrations between freshwaters and the open ocean and so provide a key form of aquatic connectivity and nutrient transport (Haro et al. 2000, Lewis 2002, Casselman 2003). Indigenous peoples have developed substantial knowledge of their spatial and seasonal distributions, habitat requirements, behavior, and migratory patterns. Cultural fishing for eels and lampreys is important for Indigenous community well-being, capacity and capability development, and the passing down of IEK among generations across Indigenous nations spanning the Pacific Ocean (Fig. 1).

Fig. 1. Indigenous fishing for eels: (A) Richard Bamblett, Lake Condah, Australia, using a traditional spear to capture kooyang and puunyuurt reed basket (photo: Denis Rose). (B) A Mi'kmaq youth in Nova Scotia learning to using a winter spear to fish for ka't (photo: Kerry Prosper).

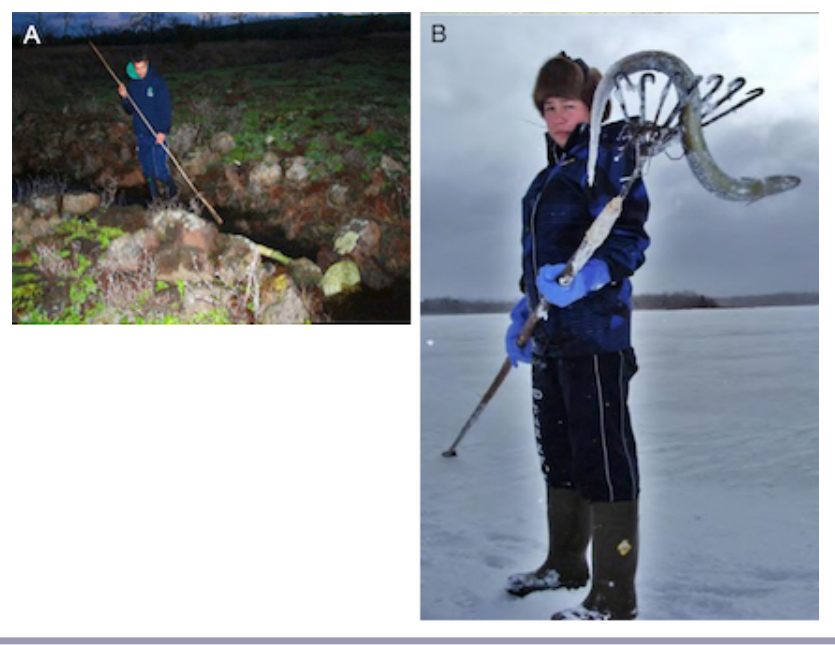


Table 2. Cultural and ecological significance of selected eel and lamprey species to Indigenous peoples in North America, Australia, and New Zealand, along with a summary of key threats and selected species-specific management plans and/or approaches where available.

\begin{tabular}{|c|c|c|c|c|c|c|}
\hline $\begin{array}{l}\text { Common and Scienti } \\
\text { Indigenous Name }\end{array}$ & $\begin{array}{l}\text { fic Name } \\
\text { Location }\end{array}$ & $\begin{array}{l}\text { Indigenous } \\
\text { Groups }\end{array}$ & $\begin{array}{l}\text { Cultural } \\
\text { Importance }\end{array}$ & Ecological Importance & Key Threats & $\begin{array}{l}\text { Management } \\
\text { Approaches }\end{array}$ \\
\hline \multicolumn{7}{|c|}{ Short-finned eel (Anguilla australis) } \\
\hline Kooyang & Australia & Gunditjmara & $\begin{array}{l}\text { Important cultural } \\
\text { subsistence fishery, } \\
\text { had historical } \\
\text { management } \\
\text { strategies } \\
\text { (Framlingham } \\
\text { Aboriginal Trust } \\
\text { and Winda Mara } \\
\text { Aboriginal } \\
\text { Corporation 2004, } \\
\text { Pease 2004, } \\
\text { McKinnon 2007, } \\
\text { Gunditjmara } \\
\text { people 2010, } \\
\text { Richards 2011). }\end{array}$ & $\begin{array}{l}\text { Once abundant, } \\
\text { nutrient cycler, apex } \\
\text { predator (McKinnon } \\
\text { 2007). }\end{array}$ & $\begin{array}{l}\text { Wetland habitat and } \\
\text { spawning ground } \\
\text { drained for } \\
\text { agriculture. } \\
\text { Commercial fishing } \\
\text { pressure } \\
\text { (Framlingham } \\
\text { Aboriginal Trust and } \\
\text { Winda Mara } \\
\text { Aboriginal } \\
\text { Corporation 2004, } \\
\text { McKinnon 2007, } \\
\text { Gunditjmara people } \\
\text { 2010). }\end{array}$ & $\begin{array}{l}\text { Recent agreements to } \\
\text { start wetland } \\
\text { restoration and } \\
\text { integrate IEK } \\
\text { (Framlingham } \\
\text { Aboriginal Trust and } \\
\text { Winda Mara } \\
\text { Aboriginal Corporation } \\
\text { 2004, McKinnon 2007, } \\
\text { Gunditjmara people } \\
\text { 2010). }\end{array}$ \\
\hline \multicolumn{7}{|c|}{ Long-finned eel and short-finned eel (Anguilla dieffenbachii and A. australis) } \\
\hline Tuna & New Zealand & Māori & $\begin{array}{l}\text { Important cultural } \\
\text { fisheries } \\
\text { throughout the } \\
\text { entire country. } \\
\text { Important in } \\
\text { ceremonial } \\
\text { practices (Best } \\
\text { 1929, Marshall } \\
\text { 1987, McDowall } \\
\text { 2011). }\end{array}$ & $\begin{array}{l}\text { Dominant part of } \\
\text { stream fish biomass, } \\
\text { apex predator, longfin } \\
\text { females are often } \\
\text { largest and oldest } \\
\text { freshwater fish. } \\
\text { Undertake mass } \\
\text { migrations. Capable of } \\
\text { occupying full range } \\
\text { of freshwater habitats } \\
\text { (McDowall 1990, } \\
\text { Chisnall and Hicks } \\
\text { 1993, NIWA 2010a, } \\
\text { Jellyman 2012). }\end{array}$ & $\begin{array}{l}\text { Instream barriers that } \\
\text { inhibit upstream and } \\
\text { downstream passage, } \\
\text { extensive loss of } \\
\text { habitat including } \\
\text { wetlands. Historical } \\
\text { extermination } \\
\text { campaigns and } \\
\text { overfishing } \\
\text { (McDowall 1990, } \\
\text { NIWA 2010a, } \\
\text { Jellyman 2012, Te Wai } \\
\text { Māori 2014). }\end{array}$ & $\begin{array}{l}\text { Recognized as } \\
\text { culturally important } \\
\text { species. Mātaitai } \\
\text { reserves allow exclusive } \\
\text { customary fisheries, } \\
\text { along with } \\
\text { comanagement } \\
\text { approaches in selected } \\
\text { waterways (Jellyman } \\
\text { 2007, Ngā Papatipu } \\
\text { Rūnanga Working } \\
\text { Group 2013, Shortland } \\
\text { 2013, New Zealand } \\
\text { Government 2010, } \\
\text { 2014c). }\end{array}$ \\
\hline \multicolumn{7}{|c|}{ American eel (Anguilla rostrata) } \\
\hline Ka't & $\begin{array}{l}\text { North } \\
\text { America }\end{array}$ & Mi'kmaq & $\begin{array}{l}\text { Important cultural } \\
\text { food source used to } \\
\text { strengthen } \\
\text { customary } \\
\text { practices. "First } \\
\text { Foods" for } \\
\text { newborn babies } \\
\text { and "Last Foods" } \\
\text { for sick and elderly } \\
\text { (Prosper 2002, } \\
\text { Davis et al. 2004, } \\
\text { Denny and Paul } \\
\text { 2010, Weiler 2011). }\end{array}$ & $\begin{array}{l}\text { Historically abundant } \\
\text { source of biomass for } \\
\text { the streams, important } \\
\text { cyclers of nutrients in } \\
\text { the stream and apex } \\
\text { predators (Haro et al. } \\
\text { 2000, Casselman } \\
\text { 2003). }\end{array}$ & $\begin{array}{l}\text { Declining access to } \\
\text { upper streams and } \\
\text { lake habitats through } \\
\text { infrastructure } \\
\text { blockages. } \\
\text { Commercial fishing } \\
\text { pressure (Haro et al. } \\
\text { 2000, Casselman 2003, } \\
\text { Weiler 2011). }\end{array}$ & $\begin{array}{l}\text { Recent treaties extend } \\
\text { Mi'kmaq Nation access } \\
\text { and commercial fishing } \\
\text { rights. Working with } \\
\text { Parks Canada to } \\
\text { integrate IEK (Prosper } \\
\text { 2002, Denny and Paul } \\
\text { 2010). }\end{array}$ \\
\hline \multicolumn{7}{|c|}{ Pacific lamprey (Lampetra tridentata) } \\
\hline ksuyas or asum & $\begin{array}{l}\text { North } \\
\text { America }\end{array}$ & $\begin{array}{l}\text { Sahaptin, } \\
\text { Nez Perce, } \\
\text { Umatilla, } \\
\text { Yakama, and } \\
\text { Warm } \\
\text { Springs }\end{array}$ & $\begin{array}{l}\text { Culturally } \\
\text { important food } \\
\text { source. Part of the } \\
\text { "First Foods" } \\
\text { ceremonies and } \\
\text { plays important } \\
\text { role in tribal } \\
\text { celebrations (Close } \\
\text { et al. 2002, } \\
\text { CRITFC 2011, } \\
\text { Dittmer 2013). }\end{array}$ & $\begin{array}{l}\text { Historical high stream } \\
\text { biomass. Provide } \\
\text { nutrient transport and } \\
\text { food for other species. } \\
\text { Filter feed and } \\
\text { influence detrital } \\
\text { cycles that positively } \\
\text { affect water quality } \\
\text { (Close et al. 2002, } \\
\text { CRITFC 2011, } \\
\text { Dittmer 2013). }\end{array}$ & $\begin{array}{l}\text { Dam infrastructure } \\
\text { blocking passageways } \\
\text { and degradation of } \\
\text { habitat. Historically } \\
\text { used by settlers for } \\
\text { salmonid fishmeal and } \\
\text { livestock feed (Close et } \\
\text { al. 2002, CRITFC } \\
\text { 2011). }\end{array}$ & $\begin{array}{l}\text { Fishery largely ignored } \\
\text { by federal, state, and } \\
\text { land-use management } \\
\text { agencies. CRITFC } \\
\text { Tribal Pacific Lamprey } \\
\text { Restoration Plan } \\
\text { started in 2011 } \\
\text { (CRITFC 2011, } \\
\text { Dittmer 2013). }\end{array}$ \\
\hline
\end{tabular}

CRITFC, Columbia River Inter-Tribal Fish Commission; IEK, Indigenous ecological knowledge. 
Table 3. Cultural and ecological significance of selected finfish species to Indigenous peoples in North America, Australia, and New Zealand, along with a summary of key threats and selected species-specific management plans and/or approaches where available.

\begin{tabular}{|c|c|c|c|c|c|c|}
\hline $\begin{array}{l}\text { Common and Scientifi } \\
\text { Indigenous Name }\end{array}$ & $\begin{array}{l}\text { Name } \\
\text { Location }\end{array}$ & Indigenous Groups & $\begin{array}{l}\text { Cultural } \\
\text { Importance }\end{array}$ & $\begin{array}{l}\text { Ecological } \\
\text { Importance }\end{array}$ & Key Threats & $\begin{array}{l}\text { Management } \\
\text { Approaches }\end{array}$ \\
\hline \multicolumn{7}{|c|}{ Murray cod (Maccullochella peelii) } \\
\hline $\begin{array}{l}\text { Pondi, Ponde, } \\
\text { Goodoo, Guddhu, } \\
\text { Ponkoo, Barnta, } \\
\text { Googoobul } \\
\text { Kurrumerruck, } \\
\text { Pandyil, Burnanga }\end{array}$ & Australia & $\begin{array}{l}\text { Murray Darling } \\
\text { River Tribes }\end{array}$ & $\begin{array}{l}\text { Cultural totem } \\
\text { with role in } \\
\text { creation of Murray } \\
\text { River. Traditional } \\
\text { food source. } \\
\text { Economic income } \\
\text { through cultural } \\
\text { ecotourism (Scott } \\
\text { 2005, Weir 2009, } \\
\text { Ginns 2012). }\end{array}$ & $\begin{array}{l}\text { Important apex } \\
\text { predator that helps } \\
\text { balance the } \\
\text { freshwater } \\
\text { ecosystem (Ebner } \\
2006) \text {. }\end{array}$ & $\begin{array}{l}\text { Habitat loss, flow } \\
\text { regulation, water } \\
\text { quality, loss to } \\
\text { irrigation systems, } \\
\text { movement barriers, } \\
\text { invasive species, } \\
\text { overfishing (Koehn } \\
\text { 2005). }\end{array}$ & $\begin{array}{l}\text { Recent recognition } \\
\text { of cultural } \\
\text { importance, } \\
\text { inclusion in species } \\
\text { management. } \\
\text { Cultural harvest } \\
\text { limit (S. Schnierer } \\
\text { and H. Egan, } \\
\text { unpublished } \\
\text { manuscript). }\end{array}$ \\
\hline \multicolumn{7}{|c|}{ Whitebait (Galaxias maculatus, G. brevipinnis, G. fasciatus, G. argenteus, and G. postvectis) } \\
\hline $\begin{array}{l}\text { İnanga, } k \bar{o} a r o, \\
\text { banded } k \bar{o} k o p u, \\
\text { giant } k \bar{o} k o p u, \text { and } \\
\text { shortjaw kōkopu }\end{array}$ & New Zealand & Māori & $\begin{array}{l}\text { Juvenile migratory } \\
\text { form is an } \\
\text { abundant food } \\
\text { source harvested in } \\
\text { large quantities, } \\
\text { which could be } \\
\text { dried for future use } \\
\text { (Best 1929, } \\
\text { McDowall 2011). } \\
\text { Presence of large } \\
\text { numbers is } \\
\text { indicator of river } \\
\text { health. }\end{array}$ & $\begin{array}{l}\text { Once made up a } \\
\text { large biomass of } \\
\text { the streams. } \\
\text { Provides a food } \\
\text { source for aquatic } \\
\text { and terrestrial } \\
\text { species (Rowe et al. } \\
\text { 2002, Department } \\
\text { of Conservation } \\
\text { 2004, McDowall } \\
\text { 2010). }\end{array}$ & $\begin{array}{l}\text { Poor water quality, } \\
\text { land-use } \\
\text { disturbance, } \\
\text { including riparian } \\
\text { and wetland } \\
\text { habitat loss, and } \\
\text { instream migration } \\
\text { barriers (Rowe et } \\
\text { al. 2002, } \\
\text { Department of } \\
\text { Conservation 2004, } \\
\text { McDowall 2010, } \\
\text { 2011, NIWA } \\
\text { 2010b). }\end{array}$ & $\begin{array}{l}\text { Whitebait fishing } \\
\text { (West Coast) } \\
\text { regulations 1994, } \\
\text { prepared under the } \\
\text { Conservation Act } \\
\text { 1986. Some } \\
\text { customary fisheries } \\
\text { management plans, } \\
\text { such as Waikato } \\
\text { River and Te Arawa } \\
\text { (Rotorua) Lakes } \\
\text { Treaty Settlements } \\
\text { (New Zealand } \\
\text { Government 2013, } \\
\text { 2014a). }\end{array}$ \\
\hline \multicolumn{7}{|c|}{ Salmon (Oncorhynchus spp.) } \\
\hline $\begin{array}{l}\text { wy-kan-ush in } \\
\text { Sahaptin }\end{array}$ & North America & $\begin{array}{l}\text { Alaska, Canada, } \\
\text { and the Pacific } \\
\text { Northwest ( } 300+ \\
\text { tribes) }\end{array}$ & $\begin{array}{l}\text { Strong cultural } \\
\text { significance, food } \\
\text { source (subsistence/ } \\
\text { commercial). First } \\
\text { salmon ceremony } \\
\text { creates sense of } \\
\text { traditional place. } \\
\text { Part of nutrition, } \\
\text { health, and } \\
\text { generational } \\
\text { knowledge transfer. } \\
\text { Cultural identity of } \\
\text { Columbia River } \\
\text { Valley "salmon } \\
\text { people" (wy-kan- } \\
\text { ush-pum) (Landeen } \\
\text { and Pinkham 1999, } \\
\text { Haggen et al. 2006, } \\
\text { Johnsen 2009, } \\
\text { Cozzetto et al. } \\
\text { 2013, Dittmer } \\
\text { 2013, CRITFC } \\
\text { 2014, Galbreath et } \\
\text { al. 2014). }\end{array}$ & $\begin{array}{l}\text { Important nutrient } \\
\text { transport across } \\
\text { both aquatic and } \\
\text { terrestrial systems. } \\
\text { Critical food } \\
\text { source for many } \\
\text { aquatic and } \\
\text { terrestrial species. } \\
\text { Considered a } \\
\text { keystone species } \\
\text { (Landeen and } \\
\text { Pinkham 1999, } \\
\text { CRITFC 2014, } \\
\text { Galbreath et al. } \\
\text { 2014). }\end{array}$ & $\begin{array}{l}\text { Habitat } \\
\text { destruction, } \\
\text { hydroelectric and } \\
\text { dam infrastructure } \\
\text { blocking } \\
\text { passageways. Poor } \\
\text { nursery stream } \\
\text { habitats. Pollution, } \\
\text { low water quality } \\
\text { and sedimentation } \\
\text { (Landeen and } \\
\text { Pinkham 1999, } \\
\text { Dittmer 2013, } \\
\text { CRITFC 2014, } \\
\text { Galbreath et al. } \\
\text { 2014). }\end{array}$ & $\begin{array}{l}\text { Intertribal basin- } \\
\text { wide plan "Spirit of } \\
\text { the Salmon," } \\
\text { Columbia River } \\
\text { Inter-Tribal Fish } \\
\text { Commission, USA. } \\
\text { Indigenous hatchery } \\
\text { to rebuild stocks. } \\
\text { Many tribes still } \\
\text { fighting for } \\
\text { customary fishing } \\
\text { rights (Landeen and } \\
\text { Pinkham 1999, } \\
\text { Haggen et al. 2006, } \\
\text { Johnsen 2009, } \\
\text { Cozzetto et al. 2013, } \\
\text { Dittmer 2013, } \\
\text { CRITFC 2014, } \\
\text { Galbreath et al. } \\
\text { 2014). }\end{array}$ \\
\hline
\end{tabular}

In North America, the Pacific lamprey (Lampetra tridentata) is considered sacred to elders of the river and is used in "First Foods" ceremonies for the Columbia River Tribes (CRITFC 2011, 2014) and for bathing and special medicinal uses (Close et al. 2002). Adult lampreys have historically been a major component of animal biomass in North American streams, and tribal members of the Yurok and Karuk tribes in Northern California have long recognized the significant role of lampreys in the Klamath River ecosystem as essential contributors of marine-derived nutrients and organic matter (Close et al. 2002, CRITFC 2011). North American First Nation tribes, such as the Mi'kmaq, also share a rich cultural history with the American eel 
Table 4. Cultural and ecological significance of freshwater mussels to Indigenous peoples in North America, Australia, and New Zealand, along with a summary of key threats and selected species-specific management plans and/or approaches where available.

\begin{tabular}{|c|c|c|c|c|c|c|}
\hline $\begin{array}{l}\text { Common and Scientif } \\
\text { Indigenous Name }\end{array}$ & $\begin{array}{l}\text { Name } \\
\text { Location }\end{array}$ & Indigenous Groups & $\begin{array}{l}\text { Cultural } \\
\text { Importance }\end{array}$ & $\begin{array}{l}\text { Ecological } \\
\text { Importance }\end{array}$ & Key Threats & $\begin{array}{l}\text { Management } \\
\text { Approaches }\end{array}$ \\
\hline \multicolumn{7}{|c|}{ Freshwater mussels (Hyriidae) } \\
\hline Tribe specific & Australia & Aboriginal & $\begin{array}{l}\text { Once an abundant } \\
\text { food source for } \\
\text { tens of thousands } \\
\text { of years as shown } \\
\text { by widespread } \\
\text { middens (Walker et } \\
\text { al. 2001, } \\
\text { Humphries 2007, } \\
\text { Humphries and } \\
\text { Winemiller 2009). }\end{array}$ & $\begin{array}{l}\text { Important filter } \\
\text { feeders and } \\
\text { nutrient cyclers in } \\
\text { the ecosystem. } \\
\text { Biological } \\
\text { indicators (Walker } \\
\text { et al. 2001, Boulton } \\
\text { et al. 2014). }\end{array}$ & $\begin{array}{l}\text { Poor river } \\
\text { regulation, } \\
\text { pollution, siltation. } \\
\text { In some places, the } \\
\text { mussels are too } \\
\text { toxic too consume } \\
\text { (Walker et al. 2001, } \\
\text { Boulton et al. } \\
2014 \text { ). }\end{array}$ & $\begin{array}{l}\text { Restoration projects } \\
\text { are slow to start } \\
\text { because of the } \\
\text { complexity of the } \\
\text { issues. }\end{array}$ \\
\hline \multicolumn{7}{|c|}{ New Zealand freshwater mussel (Echyridella menziesi) } \\
\hline $\begin{array}{l}\text { Kākahi kāeo, and } \\
\text { torewai }\end{array}$ & New Zealand & Māori & $\begin{array}{l}\text { Important } \\
\text { customary food } \\
\text { source and part of } \\
\text { spiritual practices } \\
\text { and medicinal } \\
\text { purposes, and } \\
\text { shells were used for } \\
\text { tools (Hiroa 1921, } \\
\text { McDowall 2002, } \\
\text { 2011). }\end{array}$ & $\begin{array}{l}\text { Filter feeders that } \\
\text { that cycle nutrients } \\
\text { and support good } \\
\text { water quality. } \\
\text { Biological } \\
\text { indicators } \\
\text { (McDowall 2002, } \\
\text { 2011). }\end{array}$ & $\begin{array}{l}\text { Poor river } \\
\text { regulation and } \\
\text { hydrological dam } \\
\text { infrastructure. } \\
\text { Pollution and } \\
\text { bioaccumulative } \\
\text { contaminants, } \\
\text { sedimentation, and } \\
\text { decline in host fish } \\
\text { needed to complete } \\
\text { life cycle } \\
\text { (McDowall 2002, } \\
2011 \text { ). }\end{array}$ & $\begin{array}{l}\text { A component of } \\
\text { customary fisheries } \\
\text { management plans, } \\
\text { such as the recent } \\
\text { Waikato River and } \\
\text { Te Arawa (Rotorua) } \\
\text { Lakes Treaty } \\
\text { Settlements (New } \\
\text { Zealand } \\
\text { Government 2010, } \\
\text { 2013, 2014a). }\end{array}$ \\
\hline \multicolumn{7}{|c|}{ Freshwater mussels (+300 species) } \\
\hline $\begin{array}{l}\text { Nay-ker } \\
\text { (tribe specific) }\end{array}$ & North America & $\begin{array}{l}\text { CTUIR, Tennessee } \\
\text { River, Mississippi } \\
\text { River Basin, } \\
\text { Choctawhatchee, } \\
\text { Yellow River, and } \\
\text { Conecuh Escambia } \\
\text { River Basins, USA } \\
\text { (Parmalee and } \\
\text { Klippel 1974, } \\
\text { Hughes and } \\
\text { Parmalee 1999, } \\
\text { Box et al. 2006). }\end{array}$ & $\begin{array}{l}\text { Highly exploited } \\
\text { food source for } \\
\text { tribes across North } \\
\text { America, especially } \\
\text { in winter, evidence } \\
\text { in the large shell } \\
\text { middens, up to } \\
10,000 \text { years ago } \\
\text { (Parmalee and } \\
\text { Klippel 1974, } \\
\text { Hughes and } \\
\text { Parmalee 1999, } \\
\text { Box et al. 2006). }\end{array}$ & $\begin{array}{l}\text { Critically } \\
\text { important filter } \\
\text { feeders, consume } \\
\text { detritus and } \\
\text { microorganisms } \\
\text { keeping the } \\
\text { ecosystem in } \\
\text { balance and good } \\
\text { water quality. Also } \\
\text { an important food } \\
\text { source for fish } \\
\text { species. Biological } \\
\text { indicators (Box et } \\
\text { al. 2006, } \\
\text { Machtinger et al. } \\
\text { 2007). }\end{array}$ & $\begin{array}{l}\text { Deforestation, } \\
\text { siltation, and } \\
\text { pollution of the } \\
\text { rivers. More than } \\
75 \% \text { are listed } \\
\text { extinct or } \\
\text { threatened. } \\
\text { Invasive species. } \\
\text { Historically, } \\
\text { overfished by } \\
\text { settlers for buttons } \\
\text { and livestock feed } \\
\text { (Parmalee and } \\
\text { Klippel 1974, } \\
\text { Hughes and } \\
\text { Parmalee 1999, } \\
\text { Box et al. 2006, } \\
\text { Machtinger et al. } \\
\text { 2007). }\end{array}$ & $\begin{array}{l}\text { CTUIR, tribal and } \\
\text { federal agencies are } \\
\text { working together to } \\
\text { restore freshwater } \\
\text { mussels to the } \\
\text { Umatilla River } \\
\text { Basin (Box et al. } \\
\text { 2006). }\end{array}$ \\
\hline
\end{tabular}

CTUIR, Confederated Tribes of the Umatilla Indian Reservation.

(Anguilla rostrata), or ka't, which is an important traditional food (Prosper 2002, Casselman 2003). Eeling is considered a group activity that strengthens the community groups by passing down the important customary practice to future generations (Davis et al. 2004, Denny and Paul 2010, Weiler 2011) and helping to support community bonds by sharing the catch with people not able to fish for themselves (Prosper 2002). Ka't is also part of important spiritual offerings, such as a gift to the grandfathers (Apuknajit) on the last day of January to give thanks for surviving the prior winter months (Prosper 2002). Legends of the Mi'kmaq depict eels as significant in shaping both the earth and human lives, along with interacting with other important spirits (Weiler 2011).

Across the Pacific Ocean, eels also play a key role in the lives and identity of Indigenous peoples. New Zealand freshwater eels (Anguilla dieffenbachia, A. australis, and A. reinhardtii), or tuna, were the most important freshwater fish to Māori, with this species permeating place names, proverbs (whakataukī), legends, songs (waiata), and artwork. Eels were widespread, abundant, and often grew to a large size. This is particularly true of the longfinned eel (A. dieffenbachii) that is found only in New Zealand, 
Table 5. Cultural and ecological significance of freshwater crayfish to Indigenous peoples in North America, Australia, and New Zealand, along with a summary of key threats and selected species-specific management plans and/or approaches where available.

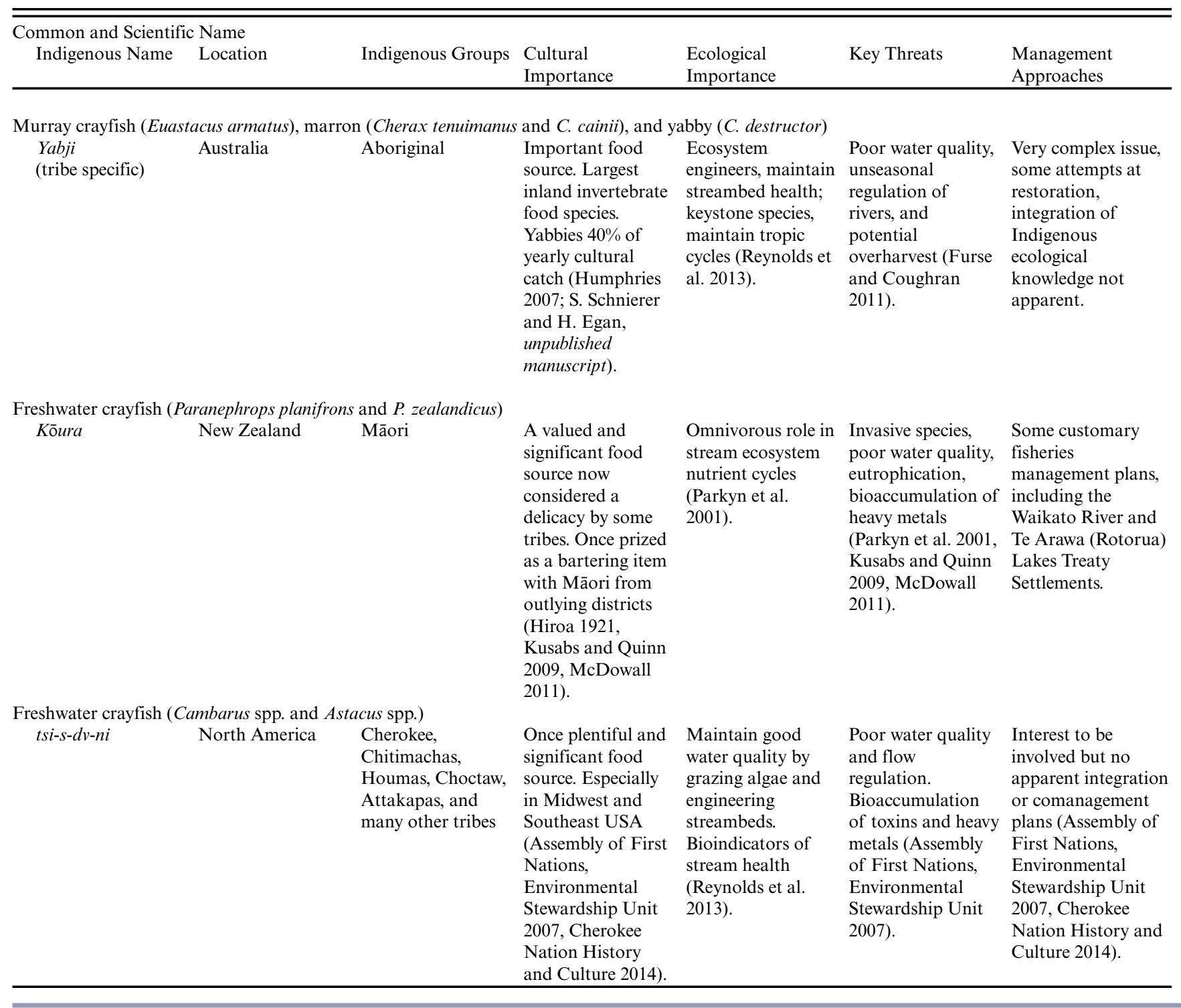

which was easy to catch and preserve and provided a critical source of dietary fat (McDowall 2011). Prior to taxonomic systems of describing eels, the Māori had many cultural names for tuna according to their coloration, season, size, behavior, locality, and palatability (e.g., McDowall 2011). In southeast Australia, the Gunditjmara people of the Budj Bim lava flow also have a long history of harvesting kooyang, or short-finned eels (A. australis), as well as the oldest known aquaculture of eels dating to 6600 years before present (Gunditjmara people 2010, Richards 2011, McNiven et al. 2012). Smoked kooyang was a treasured food source and was traded for valuable flint along the coastline, where Australian Aboriginal reliance on freshwater eels was recorded in petroglyphs (Sefton 2013) and the naming of culturally important areas, such as the Kooyang Sea Country (Gunditjmara people 2010). Kooyang continues to be a culturally important subsistence fishery for Aboriginal peoples throughout southeast Australia, with large ceremonial gatherings coinciding with the seasonal eel migrations helping to connect Indigenous people of the region to the oceans beyond Australia (Framlingham Aboriginal Trust and Winda Mara Aboriginal Corporation 2004, Pease 2004).

Ecologically, adult lampreys have historically been a major proportion of the large-bodied animal biomass within streams, where the juveniles are important detritivores and filter feeders that help to maintain good water quality and provide a food source for other animals such as salmonid fishes (Close et al. 2002, Jellyman 2012, NIWA 2013). Eels have also been a large part of the freshwater animal biomass in a wide variety of freshwater habitats, including coastal estuaries, lakes, wetlands, rivers, mountain streams, and alpine tarns, and can penetrate large distances inland (McDowall 2011). Adult eels are often the top 
predators in freshwater ecosystems and are opportunistic feeders consuming a diverse range of food, including stream insects, terrestrial insects, snails, freshwater crayfish, fish, and even small birds (Haro et al. 2000, McDowall 2011, Jellyman 2012). Through their diadromous migrations, eels also play a critical role in nutrient transport between the ocean and freshwater ecosystems (Haro et al. 2000, Casselman 2003). Given their ecological and cultural importance, eels and lampreys can be characterized as ecological keystone species and CKS, and so should be of key concern for freshwater management, research, and monitoring that considers the values, practices, and rights and interests of Indigenous peoples across these trans-Pacific nations.

\section{Other finfish}

Salmon (Oncorhynchus spp.) are a prime example of a culturally significant finfish in North America, where Native American and First Nations peoples have sustainably harvested salmon for subsistence and trade for more than 11,500 years (Table 3 ). The cultural importance of salmon is reflected in First Nations peoples of the Pacific Northwest collectively calling themselves wy-kan-ush-pum ("salmon people") where salmon are considered to unite all tribes and races of the region (CRITFC 2014). Like eels and lampreys, salmon provide a key link between freshwaters and the ocean and a food source for both aquatic and terrestrial ecosystems (Willson and Halupka 1995, Cederholm et al. 1999). Although Native American tribes have managed salmon species with a deep understanding of how to sustain healthy populations (Landeen and Pinkham 1999, Haggen et al. 2006, Johnsen 2009), severe declines since European settlement have created an urgency to restore salmon populations in freshwater ecosystems for both their cultural and ecological importance.

In Australia, Murray cod (Maccullochella peelii) have a particularly strong cultural significance for Australian Aboriginal communities living within the Murray-Darling Basin (Table 3). Being part of the dreamtime creation story of the Murray-Darling system, Murray cod play a significant role in Indigenous cultural identity (Ginns 2012). Once a significant food source, fishing for Murray cod would often occur as a group activity, with Murray cod representing $25 \%$ or more of the edible freshwater cultural catch in some areas (S. Schnierer and E. Egan, unpublished manuscript). Indigenous cultural connections to this species remain strong, despite severe regional declines since European settlement, and their important ecological role as apex predators is now well recognized (Ebner 2006).

In New Zealand, the Māori have deep cultural, social, and economic connections to the New Zealand whitebait, which are juveniles of five different Galaxias spp. (Table 3). They provide a subsistence food for the Māori who target annual whitebait migrations and preserve (dry) their catches for many months (McDowall 2011). Whitebait species have a complex life cycle that typically involves mass migrations between freshwaters and the open ocean, although several whitebait species have developed landlocked populations in river systems associated with large lakes. Whitebait provide a primary food source for many other aquatic and terrestrial species but have been overfished by European settlers (Department of Conservation 2004, McDowall 2010, 2011, Morris et al. 2013) and are now in decline across much of New Zealand because of the loss of spawning habitat, trout predation, poor water quality, and infrastructure blocking stream passageways (Department of Conservation 2004, NIWA 2010a, McDowall 2011).

Although there are many finfishes that support connections between Indigenous people and their freshwater environments, we have chosen these three species as prime examples of finfish CKS. Declines in the abundance and/or range of these species has had severe consequences for Indigenous well-being. Even though some efforts have been made to address these species declines through understanding the effects on non-Indigenous peoples, their cultural significance is yet to be fully recognized so that a more equitable approach to freshwater finfish comanagement can be fully realized.

\section{Bivalves}

Bivalves have facilitated Indigenous cultural connections to freshwaters in multiple ways (Table 4), but severe declines in bivalve diversity and abundance have severely altered contemporary Indigenous usage. Freshwater bivalves were an abundant food for Indigenous peoples in North America, New Zealand, and Australia for more than 60,000 years, with the shells used in medicines, tools, and jewelry, and incorporated into legends, songs, and proverbs (Hiroa 1921, Parmalee and Klippel 1974, Lyman 1984, Humphries and Winemiller 2009). Archeological evidence within middens indicates that Native Americans sustainably harvested freshwater mussels for at least 6000 years before the arrival of European settlers, but since then mussel biodiversity has severely declined, with $75 \%$ of U.S. freshwater mussel species endangered (Hughes and Parmalee 1999, Machtinger et al. 2007, Thorp and Covich 2010). New Zealand freshwater bivalves, or kākahilkāeo, were also once an abundant cultural resource, reflected in middens, place names, Māori tradition, legend, and mythology (McDowall 2011). Likewise, Aboriginal people in Australia sustainability harvested freshwater bivalves for more than 10,000 years within the MurrayDarling Basin, which were seen as a reliable food source by the Aboriginal people when they would travel and/or gather together for large groups during ceremonies. However, there are now minimal modern freshwater bivalve harvests by Indigenous peoples across these nations because of severe population declines arising from habitat loss, poor water quality, and pollution (Table 4). Although the ecological consequences of such losses are yet to be fully resolved, the role of bivalves in maintaining good water quality via filter feeding (Box et al. 2006, Howard and Cuffey 2006, Machtinger et al. 2007) suggests cause for serious concern. Indeed, the loss of the New Zealand freshwater mussel (Echyridella menziesi) from lake systems in New Zealand has been linked to a lowering of water quality and increased toxic phytoplankton blooms (Walker et al. 2001, McDowall 2002). Notably, natural resource management and fisheries agencies have been slow to address declines in freshwater bivalve populations, perhaps because of the lack of general public interest and/or knowledge of these species. Given the importance of this CKS group, a more formal recognition of bivalves is needed and could be addressed through better recognition of IEK for this group to reveal pre-European baselines and key information for their recovery.

\section{Crayfish}

Evidence is emerging for the cultural importance of freshwater crayfish, with their remains in middens suggesting crayfish may 
have once been an abundant food source for Indigenous communities across North America, New Zealand, and Australia (Table 5). Australian Aboriginals are thought to have utilized Murray crayfish (Euastacus armatus) as food (Kohen and Merrick 1998), and historical accounts report Aboriginal women using crayfish for body decoration (Humphries 2007). Recent research has revealed that freshwater crayfish and yabbies (Cherax destructor) are still taken in reasonable numbers for food by Aboriginal cultural fishers in parts of the Murray-Darling River basin (S. Schnierer and E. Egan, unpublished manuscript). Traditional use of freshwater crayfish (Paranephrops planifrons and P. zealandicus), or kōuralkēwai, by Māori as a food source and focal species for Māori customary practices is also evident in New Zealand. For instance, in the Te Arawa Lakes region, $k \bar{o} u r a$ are harvested using a variety of traditional methods, including the tau kōura, which involves placement of bracken fern bundles (known as whakaweku) on the lake bed, in which kōura take refuge and are captured (Hiroa 1921, Kusabs and Quinn 2009). Freshwater crayfish (Cambarus spp. and Astacus spp.) are also an abundant food source for the First Nations and the Native American people across North America (Assembly of First Nations, Environmental Stewardship Unit 2007, Cherokee Nation History and Culture 2014), particularly for the Chitimachas, Houmas, Choctaw, and Attakapas tribes of the Mississippi, Teche, and Lafourche river basin in Louisiana (Irwin 2014). Ecologically, crayfish are known to be critical for maintaining streambed health by processing detritus and cycling nutrients in freshwater ecosystems, as well as "engineering" streambed sediments via their burrowing activities (Reynolds et al. 2013). Although crayfish have started to become a target for freshwater conservation and fisheries management through their increasingly threatened status (Richman et al. 2015), their recognition as CKS would provide clearer pathways toward effective comanagement, whereby both IEK and social relevance could be integrated into their management and recovery plans.

\section{CROSS-CULTURAL APPROACHES TO CONSERVATION AND MANAGEMENT: FRESHWATER EELS AS A CASE STUDY}

Despite their cultural and ecological significance, all the freshwater animals mentioned previously have suffered severe declines as a result of environmental degradation and historical overfishing following European colonization (Revenga and Kura 2003, Dudgeon et al. 2006, Darwall et al. 2008). Such declines have greatly affected the subsistence economies of Indigenous people, who have lost access to freshwater fisheries and the ability to sustain cultural fishing practices and knowledge (Haggen et al. 2006, Dick et al. 2012). In response, many Indigenous people are driving the improved management, restoration, and conservation of freshwater species in North America, New Zealand, and Australia (e.g., Fraser et al. 2006, Woodward et al.2012, Galbreath et al. 2014). Indigenous people have been working with other agencies to develop approaches that involve cooperative, community-based, and collaborative comanagement strategies (Tipa and Welch 2006, NIWA 2010a, Hill et al. 2012). The main goal has been an equitable framework for Indigenous people to incorporate their requirements for freshwater resources and share their wealth of IEK (Jackson et al. 2012, Ens et al. 2015). We draw on trans-Pacific examples of the Mi'kmaq of Nova Scotia, the Māori of New Zealand, and the Gunditjmara of Australia to illustrate how Indigenous peoples are working to sustain, revive, and restore cultural freshwater eel fisheries (Fig. 1).

Historically, the cultural and ecological importance of eels has been overlooked by fisheries management agencies in North America, Australia, and New Zealand, probably because of their low commercial food value, conflicting social values, and community misconceptions around their role in freshwater socialcultural ecosystems (Mattson 1949, Close et al. 2002, Jellyman, 2012, Dittmer 2013). Consequently, historical eel management plans and strategies have largely failed to recognize the social impacts of the loss of important eel subsistence fisheries for Indigenous communities (Davis et al. 2004, Jellyman 2007, Gunditjmara people 2010, CRITFC 2011). Indigenous custodianship and customary fishing of eels, however, is starting to reemerge as a priority in contemporary management. For example, the Kooyang Sea Country Plan (Framlingham Aboriginal Trust and Winda Mara Aboriginal Corporation 2004) reasserts the Gunditjmara Indigenous people of southeast Australia as managers and caretakers within country declared as an Indigenous Protected Area (IPA; Weir 2009). In this IPA, the Gunditjmara people have been rehabilitating critical wetland habitats and stream connectivity for migrating eels (Framlingham Aboriginal Trust and Winda Mara Aboriginal Corporation 2004, Pease 2004, Gunditjmara people 2010). Similarly, in New Zealand, rapidly declining tuna stocks have prompted Māori-led initiatives to manage and restore critical eel habitats in freshwater ecosystems (e.g., New Zealand Government 2013, Shortland 2013, Te Wai Māori 2013). In North America, declines of $k a$ 't abundance have brought many First Nations tribes together to work on communicating the importance of these species to the wider public and developing strategies for rehabilitating eel populations on their traditional, self-governed lands (Prosper 2002, Goodbrand 2009, Denney and Paul 2010). A commonality among all of these examples is the coming together and empowerment of Indigenous tribes to rehabilitate and protect a culturally important fishery that unites many people.

Indigenous-led rehabilitation projects have often evolved into innovative comanagement strategies with local and federal governments. For example, recommendations and outcomes form the Kooyang Sea Country Plan (Framlingham Aboriginal Trust and Winda Mara Aboriginal Corporation 2004) motivated negotiations with commercial fishers and the state of Victoria to remove commercial netting in tributaries of Lake Condah, to allow eels to complete their migration and increase in abundance within this significant cultural eel fishing place (McKinnon 2007). A key aspect of this work has been collaborations between the Gunditjmara and government scientists, nongovernmental organizations, and universities to mesh cutting-edge science with traditional management practices (Gunditjmara people 2010). In New Zealand, eels are undisputed as a culturally important species, with mātaitai reserves, which are exclusive customary fishing areas, and unique comanagement approaches underway in several waterways to protect eels and the ecosystems that support them (e.g., New Zealand Government 2013, 2014d, Ngā Papatipu Rūnanga Working Group 2013). Outreach by First Nations people about the cultural importance of eels has also developed into comanagement decision-making strategies with Parks Canada to integrate IEK into management, with field monitoring by local Indigenous people (e.g., Goodbrand 2009). 
At a national level, Mi'kmaq people are also working with Environment Canada and Fisheries and Oceans Canada to identify important cultural fishing grounds that need special recognition (Weiler 2011).

Collectively, these examples around a key freshwater animal illustrate how different groups of Indigenous people have been able to use CKS recognition to motivate new management strategies. Management agencies that have traditionally overlooked cultural dimensions to eel fisheries have now become aware of their CKS status, from which comanagement and other innovative frameworks have evolved for more equitable management of both the social and ecological dimensions of these globally important fishes. Promoting the cultural importance of eels has also empowered Indigenous people to gain an equal voice in the future management plans and approaches. Ultimately, recognition of these species as keystones in both a social (CKS) and ecological sense, has provided a platform to unite nonIndigenous and Indigenous worldviews and values to progress our equitable management of freshwater ecosystems (Garibaldi and Turner 2004, Caro 2010, Butler et al. 2012).

\section{INDIGENOUS ACCESS TO FRESHWATER FISHERIES}

Recognition of Indigenous rights and needs to access culturally significant freshwater animals has been important for overcoming legal barriers to Indigenous connections to freshwaters since European settlement and colonization. Traditional use of culturally significant animals was largely determined by territorial occupation of Indigenous peoples and their complex tribal socialpolitical systems. Since European settlement, however, Indigenous peoples' access to water and cultural fishing practices has become regulated by colonizing governments that may or may not recognize such cultural traditions and values (Appendix 1). In New Zealand, Māori possession and control of taonga (all things highly prized) and management of freshwater species was originally granted in 1840 with the Treaty of Waitangi, with the second article granting rights to taonga and habitats, which encompasses fisheries (Waitangi Tribunal 1988, 1992). However, these rights have often had to be reasserted through modern legal challenges. Similarly, Native American tribes have often had to gain rights to access culturally important freshwater animals in traditional locations through legal challenges supported by the Winters water rights doctrine, inside or outside reservation lands, including private lands (Winters v. United States 1908, Osborn 2013, CRITFC 2014). Such rights can sometimes be recognized in compensation for loss, such as that made by the U.S. Congress to Native Americans who lost access to tribal fishing sites along the Columbia River after these areas were inundated by numerous dams (CRITFC 2014). In other cases, equitable Indigenous access rights have come much later after European settlement. For example, First Nations people were given the right by the Supreme Court of Canada to fish for food, ceremonial, and cultural reasons, which was applied across Canada to establish freshwater access priorities in the 1990s (see $R v$. Sparrow 1990, Issac 1999). In Australia, legal recognition for Aboriginal access to freshwater fisheries came with the passing of the Native Title Act 1993 (OPC 2014: section 211), which defines Aboriginal rights to hunting, fishing, and gathering, along with cultural and spiritual activities in relation to both land and waters (Altman 2004, Jackson and Morrison 2007, OPC 2014). Further amendments have provided the basis for other state-level legislation, such as the New South
Wales fishing legislation on Aboriginal subsistence bag limits, which recognizes the customary significance of fisheries (Schnierer 2011, New South Wales Government 2016).

In many cases, legal barriers have persisted until key challenges, often hard won, by Indigenous peoples to gain recognition that access to CKS is vital to their communities, traditional culture, and well-being. For instance, access to cultural eel fishing only came after targeted legal action by First Nations people in Canada in the Marshall case, which was monumental in defining how Indigenous access rights extend to commercial allowances and licenses and recognizing the deep cultural importance of these fisheries to the Mi'kmaq people (see $R v$. Marshall 1999a, $b$ ). This challenge was prompted by the arrest of Donald Marshall Jr. of the Membertou Band, who was charged by Fisheries and Oceans Canada for illegally fishing for $k a^{\prime} t$ without a federal commercial license to sell eels (Prosper 2002, Davis et al. 2004). Although Marshall was fishing for eels from the shores of the Paqtnkek Reservation, he was charged outside the reservation boundaries (Prosper 2002, Davis et al. 2004). Following a six-year legal battle, charges were dropped and new provisions applied to allow Indigenous eel catches for both cultural purposes and a moderate commercial livelihood (Davis et al. 2004, Denny and Paul 2010, Cooke and Murchie 2015).

A further challenge for Indigenous peoples has been securing equitable roles in the decision-making processes for rehabilitation and management of freshwater animals that are CKS. For example, in the United States, each of the state-managed freshwater fisheries are overseen and regulated by the federal government, which adjudicates and mediates the fishing rights of Native American tribes (USFWS 1994). However, the United States' Columbia River Treaty with Canada does not take into consideration the cultural importance of salmon to tribes along the river nor the ecological health of the salmon populations (CRITFC 2014). As a result, the Columbia River Inter-Tribal Fish Commission (CRITFC) has requested to be involved in a review of the treaty, which it hopes will include its "Spirit of the Salmon" plan (Wy-Kan-Ush-Mi Wa-Kish-Wit).

Although relatively recent legal treaties, policy reforms, and the implementation of freshwater management approaches that recognize and support cultural connections to freshwater fisheries are promising steps forward (e.g., USFWS 1994, 2013, UN General Assembly 2007, Armstrong 2008, Aboriginal and Torres Strait Islander Social Justice Commissioner 2009, Duff et al. 2010, Durrette 2010, Smyth et al. 2010, Schnierer 2011, Collings 2012, Osborn 2013), further challenges remain. Formal recognition of freshwater animals that are CKS for each Indigenous nation should be a priority in this regard. Although some, such as eels and salmon, have gained increasing recognition, there are many invertebrate species identified in this review that are yet to be recognized as CKS by the broader group of freshwater stakeholders and government agencies. Through recognition and subsequent protection of the rights of Indigenous people to access these CKS, we see the capacity for modern management to take better account of the dual social-ecological importance of these species and move forward to remove legal or other barriers to Indigenous access to these species. In so doing, we can develop a more inclusive approach to the adaptive management and longterm resilience of social-ecological freshwater ecosystems. 


\section{FUTURE PRIORITIES FOR MANAGING CULTURALLY SIGNIFICANT FRESHWATER ANIMALS}

Severe declines in the well-being of both freshwater animals and Indigenous peoples worldwide indicate a clear need to improve our management of freshwaters as integrated social and ecological systems. In a basic recognition of human rights, management agencies need to take special consideration of Indigenous peoples' rights to cultural catches that should be negotiated separately from recreational and commercial fishing allowances. Barriers to cultural fisheries that restrict access to CKS can lead to a loss of cultural stability and a diminution of IEK, as well as aggravate social justice issues (Nursey-Bray 2009, McCarthy et al. 2014). In seeking both social and ecological resilience in increasingly disturbed freshwater ecosystems, CKS can provide focal species for identifying and monitoring key cultural and subsistence ecosystem services that affect the resilience of both Indigenous and non-Indigenous peoples. In supporting social groups that culturally and economically rely on these species, we will also increase the potential for better management and regulation of broader ecosystem health (Berkes et al. 2000, Tipa and Teirney 2003, Moller et al. 2004, Stephenson and Moller 2009, Ruiz-Mallén and Corbera 2013). This is because many CKS are also ecological keystones that underpin key ecosystem processes that provide resistance and resilience of freshwaters to environmental disturbances. As we have explored, this approach has the potential to bolster long-term sustainability of freshwater social-ecological ecosystems through the formal recognition and inclusion of Indigenous peoples in the management of CKS around the world.

Indigenous nations have deep historical knowledge of their ecosystems, ecological constraints, presettlement baselines, and holistic management approaches that are invaluable for adaptive resource management of human connections to freshwaters (Berkes 2008, Jackson et al. 2012, McCarthy et al. 2014). This is a priceless repository of long-term observations of environmental change and adaptation methods from which we can learn how to best manage our degrading freshwater ecosystems (Berkes et al. 2000, Moller et al. 2004, Haggen et al. 2006, Cozzetto et al. 2013). Many Indigenous groups have sought to work with contemporary management agencies to develop cooperative recovery and comanagement programs that recognize their cultural connections and draw on this depth of IEK. Importantly, IEK should not be exploited without transparent processes of consideration and incorporation into management and monitoring practices (Danielsen et al. 2009, Jackson et al. 2012) according to the principles of free prior informed consent (UN General Assembly 2007). In that regard, we see collaborative research partnerships as a key way of building trust and empowering Indigenous people in shaping long-lasting partnerships to solve environmental issues as equal collaborators. Importantly, Indigenous groups are willing to help other cultures understand how they as a people have survived in these landscapes for thousands of generations, often against a background of major climatic change and uncertainty.

In recognizing a freshwater animal as an Indigenous CKS, we take the first step toward improving freshwater access rights and our management of freshwaters as resilient social-ecological systems for all stakeholders. Critical to this recognition is the adoption of collaborative groups that work with local Indigenous communities to formally recognize cultural dimensions of water rights and the importance of cultural access to freshwater fisheries (e.g., Tipa and Teirney 2003, Goodbrand 2009, Duff et al. 2010, Moggridge and Mihinui 2010, Schnierer 2011). Indigenous communities must be actively involved in the management of these species to balance competing needs and values. Effective consultation on management decisions (e.g., catch limits, listing of vulnerable species, modifications to river regulation, and availability of access) and freshwater policy changes may be best achieved through comanagement and comonitoring approaches, management plans that draw on IEK, and direct Indigenous custodianship (e.g., Indigenous rangers and IPAs). CKS also have the capacity to open cross-cultural lines of communication to build greater awareness, which in turn will optimize the recovery of the species, lead to better compliance of fisheries quotas, and build valuable partnerships. Therefore, it is important not only to formally recognize each culturally significant species, but also to follow through with active comanagement of the species so that decisions about necessary strategies, harvest allocations, and mechanisms for conservation/restoration are reached equitably for the long-term sustainability of freshwater social-ecological systems.

\section{Responses to this article can be read online at: http://www.ecologyandsociety.org/issues/responses. $\mathrm{php} / 8353$}

\section{Acknowledgments:}

We acknowledge and pay respect to the Indigenous peoples and their nations of North America, Australia, and New Zealand. Thank you to the previous generations and elders for their wisdom and strength in regaining Indigenous access rights to freshwater and aquatic resources. Thanks to C. J. Fulton for valuable discussions, and $P$. Lumley, P. Galbreath, and Z. Penney of the CRITFC for useful insights. Also, thanks to the Australian Society for Fish Biology for funding (M.N.) to attend the ASFB-ASL Congress in Darwin, 2014 Indigenous participation in research and management of aquatic ecosystems, which was the catalyst for this collaborative review.

\section{LITERATURE CITED}

Aboriginal and Torres Strait Islander Social Justice Commissioner. 2009. Case study 2: the Murray-Darling Basinan ecological and human tragedy. Pages 265-299 in Native Title Report 2008. Australian Human Rights Commission, Sydney, New South Wales, Australia. [online] URL: https://www. humanrights.gov.au/sites/default/files/content/social justice/nt report/ ntreport08/pdf/ntr2008.pdf

Aboriginal Water Initiative. 2012. Our water, our country: an information manual for Aboriginal people and the communities about the water reform process. New South Wales Department of Primary Industries, New South Wales Office of Water, Sydney, New South Wales, Australia. [online] URL: http://www.water. nsw.gov.au/ data/assets/pdf file/0004/547303/plans aboriginalcommunities water sharing our water our country.pdf 
Alfred, T. 2014. The Akwesasne cultural restoration program: a Mohawk approach to land-based education. Decolonization: Indigeneity, Education \& Society 3(3):134-144. [online] URL: http://decolonization.org/index.php/des/article/view/22233/18067

Altman, J. 2004. Indigenous interests and water property rights. Dialogue 23:29-43.

Armstrong, R. 2008. An overview of Indigenous rights in water resource management revised. Onshore and Offshore Water Rights Discussion Booklets, Lingiari Foundation. North Australian Indigenous Land and Sea Management Alliance, Darwin, Northern Territory, Australia.

Assembly of First Nations, Environmental Stewardship Unit. 2007. Traditional foods: are they safe for First Nations consumption? Assembly of First Nations, Environmental Stewardship Unit, Ottawa, Ontario, Canada. [online] URL: http://www.afn.ca/uploads/files/env/traditional_foods_safety_paper_final. pdf

Berkes, F. 2008. Sacred ecology: traditional ecological knowledge and resource management. Routledge, New York, New York, USA.

Berkes, F., J. Colding, and C. Folke. 2000. Rediscovery of traditional ecological knowledge as adaptive management. Ecological Applications 10(5):1251-1262. http://dx.doi. org/10.1890/1051-0761(2000)010[1251:roteka]2.0.co;2

Best, E. 1929. Fishing methods and devices of the Māori. Dominion Museum Bulletin 12. Dominion Museum, Wellington, New Zealand.

Blackstock, M. 2001. Water: a First Nations' spiritual and ecological perspective. B.C. Journal of Ecosystems and Management 1(1):1-14. [online] URL: http://forrex.org/sites/ $\underline{\text { default/files/publications/jem archive/ISS1/vol1 no1 art7.pdf }}$

Bohensky, E. L., and Y. Maru. 2011. Indigenous knowledge, science, and resilience: what have we learned from a decade of international literature on "integration"? Ecology and Society 16 (4):6. http://dx.doi.org/10.5751/es-04342-160406

Bond, W. J. 1994. Keystone species. Pages 237-253 in E.-D. Shulze and H. A. Mooney, editors. Biodiversity and ecosystem function. Springer-Verlag, Berlin, Germany. http://dx.doi. org/10.1007/978-3-642-58001-7 11

Boulton, A. J., M. A. Brock, B. J. Robson, D. S. Ryder, J. M. Chambers, and J. A. Davis. 2014. Australian freshwater ecology: processes and management. John Wiley and Sons, Chichester, West Sussex, UK.

Box, J. B., J. Howard, D. Wolf, C. O'Brien, D. Nez, and D. Close. 2006. Freshwater mussels (Bivalvia: Unionoida) of the Umatilla and Middle Fork John Day Rivers in Eastern Oregon. Northwest Science 80(2):95-107.

Butler, J. R. A., A. Tawake, T. Skewes, L. Tawake, and V. McGrath. 2012. Integrating traditional ecological knowledge and fisheries management in the Torres Strait, Australia: the catalytic role of turtles and dugong as cultural keystone species. Ecology and Society 17(4):34. http://dx.doi.org/10.5751/ES-05165-170434
Caro, T. 2010. Conservation by proxy: indicator, umbrella, keystone, flagship, and other surrogate species. Island, Washington, D.C., USA.

Casselman, J. M. 2003. Dynamics of resources of the American eel, Anguilla rostrata: declining abundance in the 1990s. Pages 255-274 in K. Aida, K. Tsukamoto, and K. Yamuchi, editors. Eel biology. Springer-Verlag, Tokyo, Japan. http://dx.doi. org/10.1007/978-4-431-65907-5 18

Cederholm, C. J., M. D. Kunze, T. Murota, and A. Sibatani. 1999. Pacific salmon carcasses: essential contributions of nutrients and energy for aquatic and terrestrial ecosystems. Fisheries 24 (10):6-15. http://dx.doi.org/10.1577/1548-8446(1999)024<0006: psc $>2.0 .00 ; 2$

Cherokee Nation History and Culture. 2014. Cherokee traditional foods. Cherokee Nation History and Culture, Tahlequah, Oklahoma, USA. [online] URL: http://cnhistoryonline.org/ index.php/2012-05-08-15-48-27/food-basket/68-arts/food-basket/207cherokee-traditional-foods

Chisnall, B. L., and B. J. Hicks. 1993. Age and growth of longfinned eels (Anguilla dieffenbachii) in pastoral and forested streams in the Waikato River basin, and in two hydroelectric lakes in the North Island, New Zealand. New Zealand Journal of Marine and Freshwater Research 27:317-332. http://dx.doi. org/10.1080/00288330.1993.9516572

Close, D. A., M. S. Fitzpatrick, and H. W. Li. 2002. The ecological and cultural importance of a species at risk of extinction, Pacific lamprey. Fisheries 27(7):19-25. http://dx.doi.org/10.1577/1548-8446 (2002)027<0019:teacio $>2.0$. co:2

Collings, N. 2012. Indigenous cultural \& spiritual values in water quality planning. Australian Government, Department of Sustainability, Environment, Water, Population and Communities, Canberra, Australian Capital Territory, Australia.

Columbia River Inter-Tribal Fish Commission (CRITFC). 2011. Tribal Pacific lamprey restoration plan: for the Columbia River Basin. CRITFC, Portland, Oregon, USA. [online] URL: http:// critfc.org/wp-content/uploads/2012/12/lamprey plan.pdf

Columbia River Inter-Tribal Fish Commission (CRITFC). 2014. Restoration and science: put fish back in the rivers and protect watersheds. CRITFC, Portland, Oregon, USA. [online] URL: http://www.critfc.org/fish-and-watersheds/

Cooke, S. J., and K. J. Murchie. 2015. Status of aboriginal, commercial and recreational inland fisheries in North America: past, present and future. Fisheries Management and Ecology 22 (1):1-13. http://dx.doi.org/10.1111/fme.12005

Cozzetto, K., K. Chief, K. Dittmer, M. Brubaker, R. Gough, K. Souza, F. Ettawageshik, S. Wotkyns, S. Opitz-Stapleton, S. Duren, and P. Chavan. 2013. Climate change impacts on the water resources of American Indians and Alaska Natives in the U.S. Climatic Change 120:569-584. http://dx.doi.org/10.1007/s10584-013-0852$\mathrm{y}$

Cristancho, S., and J. Vining. 2004. Culturally defined keystone species. Human Ecology Review 11(2):153-164.

Danielsen, F., N. D. Burgess, A. Balmford, P. F. Donald, M. Funder, J. P. G. Jones, P. Alviola, D. S. Balete, T. Blomley, J. 
Brashares, B. Child, M. Enghoff, J. Fjeldsa, S. Holt, H. Hübertz, A. E. Jensen, P. M. Jensen, J. Massao, M. M. Mendoza, Y. Ngaga, M. K. Poulsen, R. Rueda, M. Sam, T. Skielboe, G. Stuart-Hill, E. Topp-Jørgensen, and D. Yonten. 2009. Local participation in natural resource monitoring: a characterization of approaches. Conservation Biology 23(1):31-42. http://dx.doi.org/10.1111/ j.1523-1739.2008.01063.x

Darwall, W., K. Smith, D. Allen, M. Seddon, G. McGregor Reid, V. Clausnitzer, and V. Kalkman. 2008. Freshwater biodiversity a hidden resource under threat. Pages 1-11 in J.-C. Vié, C. HiltonTaylor, and S. N. Stuart, editors. The 2008 review of the IUCN Red List of Threatened Species. International Union for Conservation of Nature (IUCN), Gland, Switzerland. [online] URL: http://cmsdata.iucn.org/downloads/freshwater biodiversity a hidden resource under threat.pdf

Davis, A., J. Wagner, K. Prosper, and M. J. Paulette. 2004. The Paq'tnkek Mi'kmaq and ka't (American eel): a case study of cultural relations, meanings, and prospects. Canadian Journal of Native Studies 24(2):359-390.

Denny, S., and T. Paul. 2010. Cultural awareness, ecology and conservation of the American eel from a Mi'kmaq Perspective (Unama'ki). Prepared for Cape Breton Highlands National Park. Unama'ki Institute of Natural Resources, Eskasoni, Nova Scotia, Canada. [online] URL: http://www.speciesatrisk.ca/eel/documents/ Report $\% 20$ for $\% 20$ Parks $\% 20$ Canada $\% 20 \% 20$ UNAMA $\% 27$ KI.pdf

Department of Conservation. 2004. New Zealand non-migratory galaxiid fishes recovery plan: 2003-13. Threatened Species Recovery Plan 53. Department of Conservation, Wellington, New Zealand. [online] URL: http://www.doc.govt.nz/Documents/ science-and-technical/TSRP53.pdf

Dick, J., J. Stephenson, R. Kirikiri, H. Moller, and R. Turner. 2012. Listening to the kaitiaki: consequences of the loss of abundance and biodiversity of coastal ecosystems in Aotearoa New Zealand. MAI Journal 1:117-130. [online] URL: http://www. journal.mai.ac.nz/content/listening-kaitiaki-consequences-loss-abundanceand-biodiversity-coastal-ecosystems-aotearoa

Dittmer, K. 2013. Changing streamflow on Columbia basin tribal lands-climate change and salmon. Climatic Change 120:627-641. http://dx.doi.org/10.1007/s10584-013-0745-0

Dudgeon, D., A. H. Arthington, M. O. Gessner, Z.-I. Kawabata, D. J. Knowler, C. Lévêque, R. J. Naiman, A.-H. Prieur-Richard, D. Soto, M. L. J. Stiassny, and C. A. Sullivan. 2006. Freshwater biodiversity: importance, threats, status and conservation challenges. Biological Reviews 81:163-182. http://dx.doi. org/10.1017/S1464793105006950

Duff, N., K. Delfau, and M. Durette. 2010. A review of Indigenous involvement in water planning. National Water Initiative, First Peoples' Water Engagement Council, National Water Commission, Australian Government, Canberra, Australian Capital Territory, Australia. [online] URL: http://www.nwc.gov. au/_data/assets/pdf_file/0019/22564/A-review-of-Indigenous-involvementin-water-planning-Sept-2010.pdf

Durette, M. 2010. A comparative approach to Indigenous legal rights to freshwater: key lessons for Australia from the United States, Canada and New Zealand. Environmental and Planning Law Journal 27(4):296-315.
Ebner, B. 2006. Murray cod an apex predator in the Murray River, Australia. Ecology of Freshwater Fish 15(4):510-520. http://dx. doi.org/10.1111/j.1600-0633.2006.00191.x

Ens E. J., P. Pert, P. A. Clarke, M. Budden, L. Clubb, B. Doran, C. Douras, J. Giakwad, B. Gott, S. Leonard, J. Locke, J. Packer, G. Turpin, and S. Wason. 2015. Indigenous biocultural knowledge in ecosystem science and management: review and insight from Australia. Biological Conservation 181:133-149. http://dx.doi. org/10.1016/j.biocon.2014.11.008

First Peoples'Water Engagement Council(FPWEC). 2012. Policy framework: First Peoples' Water Engagement Council. Australian Government, National Water Commission, Canberra, Australian Capital Territory, Australia. [online] URL: http://www.nwc.gov. au/ data/assets/pdf file/0020/22565/Final-FPWEC-Policy-

Framework-19-March-2012.pdf

Food and Agriculture Organization of the United Nations (FAO). 2000. Code of conduct for responsible fisheries. FAO, Rome, Italy. [online] URL: http://www.fao.org/docrep/005/v9878e/v9878e00. $\underline{\mathrm{htm}}$

Framlingham Aboriginal Trust and Winda Mara Aboriginal Corporation. 2004. Kooyang Sea Country plan report. Report prepared by Smyth and Bahrdt Consultants. Framlingham Aboriginal Trust, Purnim, Victoria, Australia; and Winda Mara Aboriginal Corporation, Heywood, Victoria, Australia. [online] URL: http://www.environment.gov.au/resource/kooyang-sea-countryplan

Fraser, D. J., T. Coon, M. R. Prince, R. Dion, and L. Bernatchez. 2006. Integrating traditional and evolutionary knowledge in biodiversity conservation: a population level case study. Ecology and Society 11(2):4. [online] URL: http://www.ecologyandsociety. org/vol11/iss $2 / \operatorname{art} 4 /$

Furse, J. M., and J. Coughran. 2011. An assessment of the distribution, biology, threatening processes and conservation status of the freshwater crayfish, genus Euastacus (Decapoda, Parastacidae), in continental Australia. II. Threats, conservation assessments and key findings. Crustaceana Monographs 15:253-263. http://dx.doi.org/10.1163/ej.9789004174252.i-354.172

Galbreath, P. F., M. A. Bisbee Jr., D. W. Dompier, C. M. Kamphaus, and T. H. Newsome. 2014. Extirpation and tribal reintroduction of Coho salmon to the interior Columbia River Basin. Fisheries 39(2):77-87. http://dx.doi.org/10.1080/0363241$\underline{5.2013 .874526}$

Garibaldi, A., and N. Turner. 2004. Cultural keystone species: implications for ecological conservation and restoration. Ecology and Society 9(3):1. [online] URL: http://www.ecologyandsociety. org/vol9/iss3/art1/

Ginns, A. 2012. Murray Cod - creator of the river. Rip Rap 34:42-43. [online] URL: http://www.mdba.gov.au/kid/files/2366MD2122 RipRap 34 reduced.pdf

Goodbrand, L. 2009. Ensuring the future of the American eel in Atlantic Canada: a community partnership between Parks Canada and Aboriginal communities. Report by the Eel Project Coordinator, Fundy National Park, Parks Canada, Gatineau, Quebec, Canada. [online] URL: http://www.speciesatrisk.ca/eel/ documents $/ 5756 \mathrm{Eel}^{\%} \% 20$ project $\% 20$ summary $\% 202009$.pdf 
Government of Canada and Government of the United States of America. 2014. Treaty between the Government of Canada and the Government of the United States of America concerning Pacific salmon. Pacific Salmon Commission, Vancouver, British Columbia, Canada. [online] URL: http://www.psc.org/pubs/ Treaty/Treaty $\% 20 J u l y \% 202014 . p d f$

Gunderson, L. H. 2000. Ecological resilience - in theory and application. Annual Review of Ecology and Systematics 31:425-439. http://dx.doi.org/10.1146/annurev.ecolsys.31.1.425

Gunditjmara people. 2010. The people of Budj Bim: engineers of aquaculture, builders of stone house settlements and warriors defending country. With G. Wettenhall. Em, Mollongghip, Victoria, Australia.

Haggen, N., N. Turner, J. Carpenter, J. T. Jones, Q. Mackie, and C. Menzies. 2006. 12,000+ Years of change: linking traditional and modern ecosystem science in the Pacific Northwest. Working Paper No. 2006-02. Fisheries Centre, University of British Columbia, Vancouver, British Columbia, Canada. [online] URL: http:// publications.oceans.ubc.ca/webfm send/85

Harmsworth, G. R., R. G. Young, D. Walker, J. E. Clapcott, and T. James. 2011. Linkages between cultural and scientific indicators of river and stream health. New Zealand Journal of Marine and Freshwater Research 45(3):423-436. http://dx.doi. org/10.1080/00288330.2011.570767

Haro, A., W. Richkus, K. Whalen, A. Hoar, W.-D. Busch, S. Lary, T. Brush, and D. Dixon. 2000. Population decline of the American eel: implications for research and management. Fisheries 25 (9):7-16. http://dx.doi.org/10.1577/1548-8446(2000)025<0007: pdotae $>2.0 .00 ; 2$

Hill, R., C. Grant, M. George, C. Robinson, S. Jackson, and N. Abel, 2012. A typology of Indigenous engagement in Australian environmental management: implications for knowledge integration and social-ecological system sustainability. Ecology and Society 17(1):23. http://dx.doi.org/10.5751/ES-04587-170123

Hiroa, T. R. 1921. Maori food-supplies of Lake Rotorua, with methods of obtaining them, and usages and customs appertaining thereto. Transactions and Proceedings of the Royal Society of New Zealand 53:433-451.

Howard, J. K., and K. M. Cuffey. 2006. The functional role of native freshwater mussels in the fluvial benthic environment. Freshwater Biology 51(3):460-474. http://dx.doi.org/10.1111/ j.1365-2427.2005.01507.x

Hughes, M. H., and P. W. Parmalee. 1999. Prehistoric and modern freshwater mussel (Mollusca: Bivalvia: Unionoidea) faunas of the Tennessee River: Alabama, Kentucky, and Tennessee. Regulated Rivers: Research \& Management 15:25-42. http://dx. doi.org/10.1002/(sici)1099-1646(199901/06)15:1/3<25::aid-rrr526>3.0. $\underline{\mathrm{co} ; 2-\mathrm{k}}$

Humphries, P. 2007. Historical Indigenous use of aquatic resources in Australia's Murray-Darling Basin, and its implications for river management. Ecological Management \& Restoration 8(2):106-113. http://dx.doi.org/10.1111/

j.1442-8903.2007.00347.x
Humphries, P., and K. O. Winemiller. 2009. Historical impacts on river fauna, shifting baselines, and challenges for restoration. BioScience 59(8):673-684. http://dx.doi.org/10.1525/bio.2009.59.8.9

Irwin, S. 2014. When life gives you crawfish, make étouffée. Attakapas Gazette 2. [online] URL: http://attakapasgazette. org/2014-issue-2/life-gives-crawfish-make-etouffee/

Isaac, T. 1999. Aboriginal law cases, materials and commentaries. Purich, Saskatoon, Saskatchewan, Canada.

Jackson, S., and J. Morrison 2007. Indigenous perspectives in water management, reforms and implementation. Pages 23-41 in K. Hussey and S. Dovers, editors. Managing water for Australia: the social and institutional challenges. Commonwealth Scientific and Industrial Research Organisation, Collingwood, Victoria, Australia.

Jackson, S., P.-L. Tan, C. Mooney, S. Hoverman, and I. White. 2012. Principles and guidelines for good practice in Indigenous engagement in water planning. Journal of Hydrology 474:57-65. http://dx.doi.org/10.1016/j.jhydrol.2011.12.015

Jellyman, D. J. 2007. Status of New Zealand fresh-water eel stocks and management initiatives. ICES Journal of Marine Science 64 (7):1379-1386. http://dx.doi.org/10.1093/icesjms/fsm073

Jellyman, D. 2012. The status of longfin eels in New Zealand - an overview of stocks and harvest. Prepared for Parliamentary Commissioner for the Environment. National Institute of Water and Atmospheric Research, Christchurch, New Zealand. [online] URL: http://www.pce.parliament.nz/assets/Uploads/Jellymanreport-final2.pdf

Johnsen, D. B. 2009. Salmon, science, and reciprocity on the Northwest Coast. Ecology and Society 14(2):43. [online] URL: http://www.ecologyandsociety.org/vol14/iss2/art43/

Kahui, V., and A. C. Richards. 2014. Lessons from resource management by Indigenous Maori in New Zealand: governing the ecosystems as a commons. Ecological Economics 102:1-7. http://dx.doi.org/10.1016/j.ecolecon.2014.03.006

Koehn, J. D. 2005. The loss of valuable Murray cod in fish kills: a science and management perspective. Pages 73-82 in $\mathrm{M}$. Lintermans and B. Philllips, editors. Management of Murray cod in the Murray-Darling Basin: statement, recommendations and supporting papers. Workshop held in Canberra, 3-4 June 2004. Murray-Darling Basin Commission, Canberra, Australian Capital Territory, Australia. [online] URL: http://www.mdba.gov. au/sites/default/files/archived/native-fish/The-loss-of-Murray-codscience-perspective.pdf

Kohen, J. L., and J. R. Merrick. 1998. Limited usage of freshwater crayfishes (genus Euastacus) by Aborigines in eastern New South Wales: records and comments. Proceedings of the Linnean Society of New South Wales 119:101-105.

Kusabs, I. A., and J. M. Quinn. 2009. Use of a traditional Māori harvesting method, the tau kāura, for monitoring kāura (freshwater crayfish, Paranephrops planifions) in Lake Rotoiti, North Island, New Zealand. New Zealand Journal of Marine and Freshwater Research 43(3):713-722. http://dx.doi. org/10.1080/00288330909510036 
Landeen, D., and A. Pinkham. 1999. Salmon and his people: fish and fishing in Nez Perce culture. Confluence, Lewiston, Idaho, USA.

Langton, M. 2002. Freshwater. Pages 43-63 in Background Briefing Papers: Indigenous rights to waters. Lingiari Foundation, Broome, Western Australia, Australia.

Langton, M. 2006. Earth, wind, fire and water: the social and spiritual construction of water in Aboriginal societies. Pages 139-160 in B. David, B. Barker, and I. J. McNiven, editors. The social archaeology of Australian Indigenous societies. Aboriginal Studies, Canberra, Australian Capital Territory, Australia.

Lewis, O. Y., III 2002. Treaty fishing rights: a habitat right as part of the trinity of rights implied by the fishing clause of the Stevens Treaties. American Indian Law Review 27(1):281-311. http://dx. doi.org/10.2307/20070691

Lyman, R. L. 1984. A model of large freshwater clam exploitation in the prehistoric Southern Columbia Plateau culture area. Northwest Anthropological Research Notes 18:97-107.

Machtinger, E. T., R. Marks, W. Hohman, J. Butler, M. Patterson, K. Roe, R. M. Anderson, L. Koch, and K. Gullet. 2007. Native freshwater mussels. Fish and Wildlife Habitat Management Leaflet No. 46. U.S. Department of Agriculture, Natural Resources Conservation Service, Washington, D.C., USA. [online] URL: http://www.nrcs.usda.gov/Internet/FSE DOCUMENTS/ nrcs144p2 054084.pdf

Marsden, M., and T. A. Henare. 1992. Kaitiakitanga: a definitive introduction to the holistic world view of the Maori. Ministry for the Environment, Wellington, New Zealand. [online] URL: http:// www.marinenz.org.nz/documents/Marsden_1992_Kaitiakitanga. pdf

Marshall, Y. 1987. Maori mass capture of freshwater eels: an ethnoarchaeological reconstruction of prehistoric subsistence and social behaviour. New Zealand Journal of Archaeology 9:55-79.

Mattson, C. R. 1949. The lamprey fishery at Willamette Falls, Oregon. Fish Commission of Oregon Research Briefs 2(2):23-27.

McCarthy, A., C. Hepburn, N. Scott, K. Schweikert, R. Turner, and H. Moller. 2014. Local people see and care most? Severe depletion of inshore fisheries and its consequences for Māori communities in New Zealand. Aquatic Conservation: Marine and Freshwater Ecosystems 24:369-390. http://dx.doi.org/10.1002/ aqc. 2378

McDowall, R. M. 1990. New Zealand freshwater fishes: a natural history and guide. Heinemann, Auckland, New Zealand.

McDowall, B. 2002. Decline of the kakahi - identifying cause and effect. Water \& Atmosphere 10(4):8-9. [online] URL: https://www. niwa.co.nz/sites/niwa.co.nz/files/W\%26A10\%284\%29 8.pdf

McDowall, R. M. 2010. New Zealand freshwater fishes: an historical and ecological biogeography. Springer, Dordrecht, The Netherlands. http://dx.doi.org/10.1007/978-90-481-9271-7

McDowall, R. M. 2011. Ikawai. Freshwater fishes in Māori culture and economy. Canterbury University Press, Christchurch, New Zealand.
McHugh, P. G. 2004. Aboriginal societies and the common law: a history of sovereignty, status, and self-determination. Oxford University Press, Oxford, UK. http://dx.doi.org/10.1093/acprof: oso/9780198252481.001.0001

McKinnon, L. J. 2007. Shortfinned eel harvest capacity of the Budj Bim landscape. Final Report. Winda Mara Aboriginal Corporation, Heywood, Victoria, Australia.

McNiven, I. J., J. Crouch, T. Richards, N. Dolby, and G. Jacobsen. 2012. Dating Aboriginal stone-walled fishtraps at Lake Condah, southeast Australia. Journal of Archaeological Science 39 (2):268-286. http://dx.doi.org/10.1016/j.jas.2011.09.007

Ministry for Primary Industries (MPI). 2012. Tangata Whenua. New Zealand Government, MPI, Wellington, New Zealand. [online] URL: http://fs.fish.govt.nz/Page.aspx?pk=128

Ministry for the Environment (MFE). 2010. Māori values supplement: a supplement for the Making Good Decisions Workbook. New Zealand Government, MFE, Wellington, New Zealand. [online] URL: https://www.mfe.govt.nz/sites/default/ files/maori-values-supplement.PDF

Moggridge, B., and R. Mihinui. 2010. Guiding principles for Indigenous cultural and spiritual values on water. Australian and New Zealand Guidelines for Fresh and Marine Water Quality, National Water Quality Management Strategy. Australian Government, Canberra, Australian Capital Territory, Australia.

Moller, H., F. Berkes, P. O. Lyver, and M. Kislalioglu. 2004. Combining science and traditional ecological knowledge: monitoring populations for co-management. Ecology and Society 9(3):2. [online] URL: http://www.ecologyandsociety.org/vol9/ iss $3 /$ art 2

Morris, B., C. van Schravendijk-Goodman, J. Williams, and G Ormsby. 2013. Identifying traditional whitebait stands in the lower Waikato River - a joint spatial analysis project. Technical Report 2013/18. Waikato Regional Council, Hamilton, New Zealand. [online] URL: http://www.waikatoregion.govt.nz/TR201318/

National Cultural Flows Research Project. 2014. About the project. National Cultural Flows Planning and Research Committee, Melbourne, Victoria, Australia. [online] URL: $\underline{\text { http:// }}$ culturalflows.com.au/about.html

National Institute of Water and Atmospheric Research (NIWA). 2010a. Waikato River independent scoping study. NIWA Client Report, HAM2010-032. NIWA, Hamilton, New Zealand. [online] URL: http://www.mfe.govt.nz/sites/default/files/wrissfinal-report.pdf

National Institute of Water and Atmospheric Research (NIWA). 2010b. Appendix 6: whitebait. In Waikato River independent scoping study. NIWA, Hamilton, New Zealand. [online] URL: http://www.waikatoriver.org.nz/wp-content/uploads/2014/09/6-Whitebait. pdf

National Institute of Water and Atmospheric Research (NIWA). 2013. Mahinga kai - what species interests you? NIWA, Auckland, New Zealand. [online] URL: http://www.niwa.co.nz/our-science/ freshwater/tools/kaitiaki tools/species

National Water Commission (NWC). 2012. Position statement: Indigenous access to water resources. Australian Government, 
NWC, Canberra, Australian Capital Territory, Australia. [online] URL: http://www.nwc.gov.au/_data/assets/pdf file/0009/22869/ Indigenous-Position-Statement-June-2012.pdf

New South Wales Government. 2016. Fisheries Management Act 1994 No. 38. New South Wales Government, New South Wales Legislation, Sydney, New South Wales, Australia. [online] URL: http://www.legislation.nsw.gov.au/inforcepdf/1994-38.pdf?id=53064386a8f5-4202-b6b1-5ffe33870b89

New Zealand Government. 2010. Fisheries (south-east area commercial fishing) regulations 1986 (SR 1986/219). Reprint. New Zealand Government, Parliamentary Counsel Office, Wellington, New Zealand. [online] URL: http://www.legislation. govt.nz/regulation/public/1986/0219/22.0/DLM109259.html

New Zealand Government. 2013. Waikato-Tainui (Waikato River fisheries) regulations 2011 (SR 2011/294). Reprint. New Zealand Government, Parliamentary Counsel Office, Wellington, New Zealand. [online] URL: http://www.legislation.govt.nz/regulation/ public/2011/0294/latest/DLM3930995.html

New Zealand Government. 2014a. Fisheries (amateur fishing) regulations 1986 (SR 1986/221). Reprint. New Zealand Government, Parliamentary Counsel Office, Wellington, New Zealand. [online] URL: http://www.legislation.govt.nz/regulation/ public/1986/0221/latest/DLM112671.html

New Zealand Government. 2014b. Fisheries (Kaimoana customary fishing) regulations 1998 (SR 1998/434). Reprint. New Zealand Government, Parliamentary Counsel Office, Wellington, New Zealand. [online] URL: http://www.legislation.govt.nz/ regulation/public/1998/0434/latest/DLM267987.html

New Zealand Government. 2014c. Fisheries (South Island customary fishing) regulations 1999 (SR 1999/342). Reprint. New Zealand Government, Parliamentary Counsel Office, Wellington, New Zealand. [online] URL: http://www.legislation.govt.nz/ regulation/public/1999/0342/latest/DLM296893.html.

New Zealand Government. 2014d. Waikato-Tainui Raupatu Claims (Waikato River) Settlement Act 2010, public act 2010 no. 24. New Zealand Government, Parliamentary Counsel Office, Wellington, New Zealand. [online] URL: http://www.legislation. govt.nz/act/public/2010/0024/latest/DLM1630002.html

New Zealand Government. 2015. Treaty of Waitangi Act 1975, No. 114. Reprint. New Zealand Government, Parliamentary Counsel Office, Wellington, New Zealand. [online] URL: http:// www.legislation.govt.nz/act/public/1975/0114/latest/DLM435368. $\underline{\mathrm{html}}$

Ngā Papatipu Rūnanga Working Group. 2013. Mahaanui Iwi management plan 2013. Mahaanui Kurataiao, Christchurch, New Zealand. [online] URL: http://mkt.co.nz/mahaanui-iwi-managementplan/Mahaanui-IMP-web.pdf

Nursey-Bray, M. 2009. A Guugu Yimmithir Bam Wii: Ngawiya and Girrbithi: hunting, planning and management along the Great Barrier Reef, Australia. Geoforum 40:442-453. http://dx. doi.org/10.1016/j.geoforum.2009.02.002

Office of Parliamentary Counsel (OPC). 2014. Native Title Act 1993: No. 110, 1993 as amended. Australian Government, OPC, Canberra, Australian Capital Territory, Australia. [online] URL: http://www.comlaw.gov.au/Details/C2014C00631
Office of the United Nations High Commissioner for Human Rights (OHCHR). 1976a. International covenant on civil and political rights. General Assembly Resolution 2200A, Article 49. OHCHR, Geneva, Switzerland. [online] URL: http://www.ohchr. org/Documents/ProfessionalInterest/ccpr.pdf

Office of the United Nations High Commissioner for Human Rights (OHCHR). 1976b. International covenant on economic, social and cultural rights. General Assembly Resolution 2200A, Article 27. OHCHR, Geneva, Switzerland. [online] URL: $\underline{\text { http:// }}$ www.ohchr.org/Documents/ProfessionalInterest/cescr.pdf

Osborn, R. P. 2013. Native American Winters doctrine and Stevens Treaty water rights: recognition, quantification, management. American Indian Law Journal 2(1):76-113.

Paramlee, P. W., and W. E. Klippel. 1974. Freshwater mussels as prehistoric food resource. American Antiquity 39(3):421-434. http://dx.doi.org/10.2307/279431

Parkyn, S. M., K. J. Collier, and B. J. Hicks. 2001. New Zealand stream crayfish: functional omnivores but trophic predators? Freshwater Biology 46(5):641-652. http://dx.doi.org/10.1046/ j.1365-2427.2001.00702.X

Pease, B. C. 2004. Description of the biology and an assessment of the fishery for adult longfinned eels in NSW. Fisheries Final Report Series, No. 69. New South Wales Department of Primary Industries, Cronulla, New South Wales, Australia. [online] URL: http://www.dpi.nsw.gov.au/_data/assets/pdf_file/0014/140261/part1Longfinned-eels-introduction.pdf

Prosper, K. 2002. The Paq'tnkek Mi'kmaq and Kat (American eel-Anguilla rostrata). Social Research for Sustainable Fisheries (SRSF) Research Report No. 4. SRSF, St. Francis Xavier University, Antigonish, Nova Scotia, Canada. [online] URL: http://www.msvu.ca/site/media/msvu/Report4.pdf

Prosper, K., L. J. McMillan, A. A. Davis, and M. Moffitt. 2011. Returning to Netukulimk: Mi'kmaq cultural and spiritual connections with resource stewardship and self-governance. International Indigenous Policy Journal 2(4):7. http://dx.doi. org/10.18584/iipj.2011.2.4.7

Revenga, C., and Y. Kura. 2003. Status and trends of biodiversity of inland water ecosystems. Technical Series No. 11. Secretariat of the Convention on Biological Diversity, Montreal, Quebec, Canada. [online] URL: https://www.cbd.int/doc/publications/ cbd-ts-11.pdf

Reynolds, J., C. Souty-Grosset, and A. Richardson. 2013. Ecological roles of crayfish in freshwater and terrestrial habitats. Freshwater Crayfish 19(2):197-218.

Richards, T. 2011. A late nineteenth-century map of an Australian Aboriginal fishery at Lake Condah. Australian Aboriginal Studies 2:64-87.

Richman, N. I., M. Bohm, S. B. Adams, F. Alvarez, E. A. Bergey, J. J. S. Bunn, Q. Burnham, J. Cordeiro, J. Coughran, K. A. Crandall, K. L. Dawkins, R. J. DiStefano, N. E. Doran, L. Edsman, A. G. Eversole, L. Füreder, J. M. Furse, F. Gherardi, P. Hamr, D. M. Holdich, P. Horwitz, K. Johnston, C. M. Jones, J. P. G. Jones, R. L. Jones, T. G. Jones, T. Kawai, S. Lawler, M. López-Mejía, R. M. Miller, C. Pedraza-Lara, J. D. Reynolds, A. M. M. Richardson, M. B. Schultz, G. A. Schuster, P. J. Sibley, C. 
Souty-Grosset, C. A. Taylor, R. F. Thoma, J. Walls, T. S. Walsh, and B. Collen. 2015. Multiple drivers of decline in the global status of freshwater crayfish (Decapoda: Astacidea). Philosophical Transactions of the Royal Society of London, Series B 370 (1662):20140060. http://dx.doi.org/10.1098/rstb.2014.0060

Roberts, M., W. Norman, N. Minhinnick, D. Wihongi, and C. Kirkwood 1995. Kaitiakitanga: Maori perspectives on conservation. Pacific Conservation Biology 2(1):7-20.

Rowe, D. K., G. Konui, and K. D. Christie. 2002. Population structure, distribution, reproduction, diet, and a relative abundance of koaro (Galaxias brevipinnis) in a New Zealand lake. Journal of the Royal Society of New Zealand 32:275-291. http:// dx.doi.org/10.1080/03014223.2002.9517695

Ruiz Mallén, I., and E. Corbera. 2013. Community-based conservation and traditional ecological knowledge: implications for social-ecological resilience. Ecology and Society 18(4):12. http://dx.doi.org/10.5751/ES-05867-180412

$R$ v. Marshall, No. 1 [1999a] 3 S.C.R. 456. Judgments of the Supreme Court of Canada, Montreal, Quebec, Canada. [online] URL: http://scc-csc.lexum.com/scc-csc/scc-csc/en/item/1739/index. $\underline{\text { do }}$

$R$ v. Marshall, No. 2 [1999b] 3 S.C.R. 533. Judgments of the Supreme Court of Canada, Montreal, Quebec, Canada. [online] URL: $\underline{\text { http://scc-csc.lexum.com/scc-csc/scc-csc/en/item/1740/index. }}$ $\underline{\text { do }}$

$R$ v. Sparrow, [1990] 1 S.C.R. 1075. Judgments of the Supreme Court of Canada, Montreal, Quebec, Canada. [online] URL: http://scc-csc.lexum.com/scc-csc/scc-csc/en/item/609/index.do

Schnierer, S. 2011. Aboriginal fisheries in New South Wales: determining catch, cultural significance of species and traditional fishing knowledge needs. Final Report. Fisheries Research and Development Corporation, Canberra, Australian Capital Territory, Australia. [online] URL: http://www.dpi.nsw.gov.au/ data/assets/pdf_file/0018/423207/Aboriginal-fisheries-in-NSWdetermining.pdf

Schnierer, E., S. Ellsmore, and S. Schnierer. 2011. State of Indigenous cultural heritage 2011. Report prepared for Australian Government Department of Sustainability, Environment, Water, Population and Communities (DSEWPaC) on behalf of the State of the Environment 2011 Committee. DSEWPaC, Canberra, Australian Capital Territory, Australia. [online] URL: http:// www.environment.gov.au/system/files/pages/3f0dc683-4f21-4611-95f8f6604297c916/files/soe2011-supplementary-heritage-state-indigenouscultural-heritage.pdf

Scott, A. 2005. Historical evidence of native fish in the MurrayDarling Basin at the time of European settlement - from the diaries of the first explorers. Australian Government, Cooperative Research Centre for Freshwater Ecology, Canberra, Australian Capital Territory, Australia. [online] URL: http://www.dpi.nsw. gov.au/ data/assets/pdf file/0003/186951/Historical-evidence-ofnative-fish-in-the-Murray-Darling.pdf

Secretariat of the Convention on Biological Diversity. 2005. Handbook of the Convention on Biological Diversity including its Cartagena Protocol on Biosafety. Third edition. Secretariat of the
Convention on Biological Diversity, Montreal, Quebec, Canada. [online] URL: https://www.cbd.int/doc/handbook/cbd-hb-all-en. pdf

Sefton, C. 2013. Molluscs and fish in the rock art of the coast, estuary and hinterland of the Woronora Plateau, NSW. Rock Art Research: Journal of the Australian Rock Art Research Association (AURA) 30(1):97-102.

Shortland, T. 2013. Kete Tangariki - pilot tuna enhancement project. Te Wai Māori Trust, Aotearoa, New Zealand. [online] URL: https://www.cbd.int/financial/micro/newzealand-kete-tangariki. pdf

Smyth, D., M. Isherwood, and S. Schnierer. 2010. Right to use country: towards a freestanding statutory right for Traditional Owners to non-commercial access to and use of natural resources in Victoria. Final Report. Victorian Department of Justice, Native Title Unit, Melbourne, Victoria, Australia. [online] URL: http:// www.marineparksaudit.nsw.gov.au/imagesDB/news/312. RighttoUseCountry Report.pdf

Stephenson, J., and H. Moller. 2009. Cross-cultural environmental research and management: challenges and progress. Journal of the Royal Society of New Zealand 39 (4):139-149. http://dx.doi.org/10.1080/03014220909510567

Te Wai Māori. 2013. Te Wai Māori trust annual plan 2013: protecting and enhancing Māori interests in freshwater fisheries. Te Wai Māori, Wellington, New Zealand. [online] URL: $\underline{\text { http:// }}$ waimaori.maori.nz/documents/publications/wai-maori-annual-plan-2013. pdf

Te Wai Māori. 2014. Water quality, quantity keys to restoring eel populations. Media Release, 25 June. Te Wai Māori, Wellington, New Zealand. [online] URL: http://waimaori.maori.nz/ media/25.06.14. Water-quality-quantity-keys-to-restoring-eel-populations. $\underline{\mathrm{htm}}$

Thorp, J. H, and A. P. Covich. 2010. Ecology and classification of North American freshwater invertebrates. Third edition. Academic, London, UK.

Tipa, G. T. 2013. Bringing the past into our future - using historic data to inform contemporary freshwater management. Kōtuitui: New Zealand Journal of Social Sciences Online 8(1-2):40-63. http://dx.doi.org/10.1080/1177083x.2013.837080

Tipa, G., and L. D. Teirney. 2003. A cultural health index for streams and waterways: indicators for recognising and expressing Māori values. Ministry for the Environment, Wellington, New Zealand. [online] URL: http://www.stats.govt.nz/ /media/ Statistics/surveys-and-methods/methods/indicator-guidelines/culturalhealth-index-jun03.pdf

Tipa, G., and R. Welch. 2006. Comanagement of natural resources: issues of definition from an Indigenous community perspective. Journal of Applied Behavioral Science 42:373-391. http://dx.doi.org/10.1177/0021886306287738

United Nations (UN) General Assembly. 1992. Rio declaration on environment and development. Report of the United Nations Conference on Environment and Development (Rio de Janeiro, 3-14 June 1992). A/CONF.151/26(Vol. I). UN General Assembly, 
New York, New York, USA. [online] URL: http://www.un.org/ documents/ga/conf151/aconf15126-1annex1.htm

United Nations (UN) General Assembly. 2007. United Nations declaration on the rights of Indigenous peoples. A/RES/61/295. UN General Assembly, New York, New York, USA. [online] URL: http://www.un.org/esa/socdev/unpfii/documents/DRIPS en.pdf

United Nations Sustainable Development. 1992. Agenda 21. United Nations Conference on Environment and Development (Rio de Janeiro, 3-14 June 1992). United Nations, New York, New York, USA. [online] URL: https://sustainabledevelopment.un. org/content/documents/Agenda21.pdf

U.S. Fish and Wildlife Service (USFWS). 1994. The Native American policy of the U.S. Fish and Wildlife Service. U.S. Department of the Interior, USFWS, Washington, D.C., USA. [online] URL: http://www.fws.gov/northeast/nativeamerican/ PDFs/NAPolicy.pdf

U.S. Fish and Wildlife Service (USFWS). 2013. Native American liaison. Office of External Affairs, Massachusetts, USA. [online] URL: http://www.fws.gov/nativeamerican/

Waitangi Tribunal. 1988. Report of the Waitangi Tribunal on the Muriwhenua fishing claim. WAI 22. Department of Justice, Waitangi Tribunal, Wellington, New Zealand. [online] URL: http://www.justice.govt.nz/tribunals/waitangi-tribunal/Reports/wai0022\% 20Main

Waitangi Tribunal. 1992. The Ngai Tahu sea fisheries report. WAI 27. Department of Justice, Waitangi Tribunal, Wellington, New Zealand. [online] URL: http://www.justice.govt.nz/tribunals/ waitangi-tribunal/Reports/wai0027\%20Sea $\% 20$ Fisheries

Waitangi Tribunal. 2011. Ko Aotearoa Tēnei: a report into claims concerning New Zealand law and policy affecting Māori culture and identity. Te Taumata Tuatahi, WAI 262. Legislation Direct, Wellington, New Zealand. [online] URL: https://forms.justice. govt.nz/search/Documents/WT/wt DOC 68356054/

$\underline{\text { KoAotearoaTeneiTT1W.pdf }}$

Walker, K. F., M. Byrne, C. W. Hickey, and D. S. Roper. 2001. Freshwater mussels (Hyriidae) of Australasia. Pages 5-31 in G. Bauer and K. Wächtler, editors. Ecology and evolution of the freshwater mussels Unionoida. Springer, Berlin, Germany. http:// dx.doi.org/10.1007/978-3-642-56869-5 2

Weiler, M. H. 2011. Mi'kmaq and the American eel: traditional knowledge relating to the American eel by mainland Nova Scotia Mi'kmaq. Aboriginal Fund for Species at Risk Project No. 1734. Environment Canada and Fisheries and Oceans Canada, Dartmouth, Nova Scotia, Canada.

Weir, J. 2009. The Gunditjmara land justice story. Australian Institute of Aboriginal and Torres Strait Islander Studies, Native Title Research Unit, Canberra, Australian Capital Territory, Australia.

Willson, M. F., and K. C. Halupka. 1995. Anadromous fish as keystone species in vertebrate communities. Conservation Biology 9(3):489-497. http://dx.doi.org/10.1046/j.1523-1739.1995.09030489. $\underline{\mathrm{X}}$
Winters v. United States, No. 158, 207 U.S. 564 (1908). U.S. Supreme Court, Washington, D.C., USA. [online] URL: https:// supreme.justia.com/cases/federal/us/207/564/

Woodward, E., S. Jackson, M. Finn, and P. M. McTaggart. 2012. Utilising Indigenous seasonal knowledge to understand aquatic resource use and inform water resource management in northern Australia. Ecological Management \& Restoration 13(1):58-64. http://dx.doi.org/10.1111/j.1442-8903.2011.00622.x 
Appendix 1. Water policies, treaties, and agreements that support the rights of Indigenous peoples' access to freshwaters and/or culturally significant freshwater fisheries.

\begin{tabular}{|c|c|c|c|c|}
\hline Country & $\begin{array}{l}\text { Governance } \\
\text { Level }\end{array}$ & Rights & Meanings & Notes \\
\hline International & $\begin{array}{l}\text { International } \\
\text { Conventions } \\
\text { and Treaties }\end{array}$ & $\begin{array}{l}\text { International Covenant on } \\
\text { Civil and Political Rights } \\
(\text { OHCHR 1976a), } \\
\text { International Covenant on } \\
\text { Economic, Social and } \\
\text { Cultural Rights (OHCHR } \\
\text { 1976b), } \\
\text { Agenda } 21 \text { (United Nations } \\
\text { Sustainable Development } \\
\text { 1992), the Rio Declaration } \\
\text { (UN General Assembly } \\
\text { 1992), United Nations } \\
\text { Convention on Biodiversity } \\
\text { (Secretariat of the } \\
\text { Convention on Biological } \\
\text { Diversity 2005), and UN } \\
\text { Food and Agriculture } \\
\text { Organization: Code of } \\
\text { Conduct for Responsible } \\
\text { Fisheries (FAO 2000). }\end{array}$ & $\begin{array}{l}\text { Various International } \\
\text { agreements have been } \\
\text { made that includes the } \\
\text { United States, Australia } \\
\text { and New Zealand along } \\
\text { with other countries to } \\
\text { equitability grant access to } \\
\text { freshwater and freshwater } \\
\text { species by Indigenous } \\
\text { peoples (OHCHR 1976a, } b \text {, } \\
\text { UN General Assembly } \\
\text { 1992, United Nations } \\
\text { Sustainable Development } \\
\text { 1992, FAO 2000, } \\
\text { Secretariat of the } \\
\text { Convention on Biological } \\
\text { Diversity 2005). }\end{array}$ & $\begin{array}{l}\text { Many of the International } \\
\text { agreements have } \\
\text { mentioned or contain } \\
\text { clauses encouraging the } \\
\text { inclusion of Indigenous } \\
\text { people as equal } \\
\text { stakeholders in freshwater } \\
\text { negotiations, conservation, } \\
\text { and access to culturally } \\
\text { significant species. }\end{array}$ \\
\hline
\end{tabular}

United

Nations
United Nations Declaration on the Rights of Indigenous Peoples (UN General Assembly 2007)

Sovereignty
Promote the right to participate in decisionmaking in regards to water, continue the right to maintain cultural connections to water and land, and ensure proper consultation for any changes to water access, which also includes fisheries species (UN General Assembly 2007, FPWEC 2012).

Federally each country recognizes Indigenous Tribes and Nations as domestic independent nations with inherent rights of self-governance.

Treaties, court decisions and tribal legislation help to govern relationships between tribes and entities (McHugh 2004, Durette 2010, Osborn 2013).
World agreement on the rights of Indigenous peoples', but does not have legal standing.

Respects the selfdetermination of the each Tribe and Nation to have economic security and management of their freshwater resources. 
Appendix 1. continued.

\begin{tabular}{|c|c|c|c|c|}
\hline Country & $\begin{array}{l}\text { Governance } \\
\text { Level }\end{array}$ & Rights & Meanings & Notes \\
\hline \multirow[t]{3}{*}{ Australia } & National & $\begin{array}{l}\text { Native Title Act } 1993 \\
\text { (OPC 2014) }\end{array}$ & $\begin{array}{l}\text { Customary water access } \\
\text { recognized through leases, } \\
\text { licenses and permits } \\
\text { (Altman 2004, Jackson and } \\
\text { Morrison 2007, Aboriginal } \\
\text { and Torres Strait Islander } \\
\text { Social Justice } \\
\text { Commissioner 2009, OPC } \\
\text { 2014) }\end{array}$ & $\begin{array}{l}\text { Section } 211 \text { of the Act } \\
\text { protects the fishing right of } \\
\text { Native Title Holders } \\
\text { (Schnierer et al. } 2011 \text {, OPC } \\
\text { 2014). }\end{array}$ \\
\hline & & $\begin{array}{l}\text { Cultural Flows (National } \\
\text { Cultural Flows Research } \\
\text { Project 2014) }\end{array}$ & $\begin{array}{l}\text { Flow allocation } \\
\text { requirement to Indigenous } \\
\text { peoples through the } \\
\text { Murray-Darling Basin } \\
\text { (FPWEC 2012, NWC } \\
\text { 2012, National Cultural } \\
\text { Flows Research Project } \\
\text { 2014). }\end{array}$ & $\begin{array}{l}\text { Concept is still in the early } \\
\text { stages of implementation. } \\
\text { Objectives include } \\
\text { establishing river flows } \\
\text { that support cultural } \\
\text { connections, facilitate } \\
\text { economic development, } \\
\text { and promote the recovery } \\
\text { of culturally significant } \\
\text { fisheries (tribe specific). }\end{array}$ \\
\hline & State & Various & $\begin{array}{l}\text { Every state has different } \\
\text { access rights for } \\
\text { Indigenous people and } \\
\text { customary fisheries access } \\
\text { (Smyth et al. 2010, }\end{array}$ & $\begin{array}{l}\text { Complex situation of each } \\
\text { state having its own } \\
\text { regulations on Aboriginal } \\
\text { rights to access freshwater } \\
\text { fisheries. }\end{array}$ \\
\hline
\end{tabular}

Schnierer 2011, Schnierer et al. 2011, FPWEC 2012, NWC 2012).

Canada and National USA

Canada

National
$R$ v. Sparrow 1990 ( $R v$. Sparrow 1990)

$R v$. Marshall 1999 ( $R v$. Marshall 1999a, b)
Pacific Salmon Treaty 1985 (Government of Canada and Government of the United States of America 2014)

Treaty between Canada and the USA to recognize the importance of cross boundary migrations of salmon (CRITFC 2014, Government of Canada and Government of the United States of America 2014).

Supreme Court of Canada declared that First Nations People had the right to fish for food, ceremonial and cultural reasons $(R v$. Sparrow 1990, Issac 1999, CRITFC 2014).

Supreme Court of Canada ruled that First Nations People had the legal right to fish for commercial purposes ( $R$ v. Marshall $1999 a, b)$.
Mentions the treaty should meet objectives with Native Americans and First Nations people, but often they are not active participants in negotiations. CRITFC is working to be a part of recent review of the treaty (CRITFC 2014).

Ruling applies Canada wide.

Gives the First Nations people the right to continue to fish for CKS for economic reasons. 
Appendix 1. continued.

\begin{tabular}{|c|c|c|c|}
\hline Country & $\begin{array}{l}\text { Governance } \\
\text { Level }\end{array}$ & Rights & Meanings \\
\hline \multirow[t]{2}{*}{$\begin{array}{c}\text { New } \\
\text { Zealand }\end{array}$} & National & $\begin{array}{l}\text { Treaty of Waitangi Act } \\
1975 \text { (New Zealand } \\
\text { Government 2015) }\end{array}$ & $\begin{array}{l}\text { National treaty that defines } \\
\text { Māori relationships to } \\
\text { freshwater resources and } \\
\text { grants the right to access, } \\
\text { along with the right to be } \\
\text { consulted during decision- } \\
\text { making processes (MFE } \\
\text { 2010, Harmsworth et al. } \\
\text { 2011, New Zealand } \\
\text { Government 2015). }\end{array}$ \\
\hline & & $\begin{array}{l}\text { Regulation 27A of } \\
\text { Fisheries (Amateur } \\
\text { Fishing) Regulations } 1986 \\
\text { (New Zealand Government } \\
\text { 2014a: regulation 27A), } \\
\text { Kaimoana Customary } \\
\text { Fishing Regulations } 1998 \\
\text { (New Zealand Government } \\
\text { 2014b), and South Island } \\
\text { Customary Fishing } \\
\text { Regulations } 1999 \text { (New } \\
\text { Zealand Government } \\
\text { 2014c) }\end{array}$ & $\begin{array}{l}\text { National guidelines to } \\
\text { protect customary fishing } \\
\text { practices and allows for } \\
\text { ceremonial catches (MPI } \\
2012, \text { New Zealand } \\
\text { Government 2014a: } \\
\text { regulation } 27 \mathrm{~A}, \text { New } \\
\text { Zealand Government } \\
2014 b, c) \text {. }\end{array}$ \\
\hline
\end{tabular}

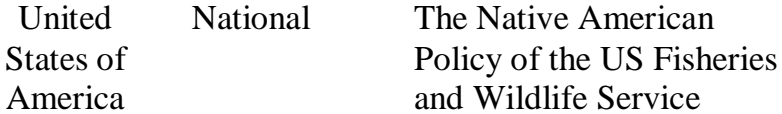

(USFWS 2013)

Winters Water Rights Doctrine (Winters $v$. United States 1908)

Stevens Treaties
Policy that guides requires the Federal government to negotiate rights with individual Native American Tribes and helps to guide the co-management fisheries (Osborn 2013, USFWS 2013).

Gives tribes the legal right to access cultural important species off of reservations and gives the individual Native American Tribes access to water on reservations (Winters $v$. United States 1908, Lewis 2002, Osborn 2013, USFWS 2013).

Gives Native Americans the rights to fish and to have enough water allocated to the reservations to support a healthy population of cultural important fisheries (Winters v. United States 1908, Lewis 2002, Osborn 2013, USFWS 2013).
Notes

Defines rights as a stakeholder in water management. Validity and roles are still unclear.

Directs councils to recognize and support of the Māori relationship to freshwater.

Defines on and off reservation management with no clear details of the management of individual species. Allows for legal cultural harvest of fish off reservation.

Guarantee allocation of water for the reservation in terms of water used for agriculture.

Water allocations include the right to support a healthy population of fish species. 